\title{
Особенности фармакологической регуляции функционального состояния пожилых людей
}

\author{
Валентина В. Тонковцева ${ }^{1}$, Инна А. Батура', Елена В. Воробьева ${ }^{2}$, Алексей А. Буриков ${ }^{3}$ \\ ${ }^{1}$ ФГБУН «Ордена трудового красного знамени Никитский ботанический сад - \\ Национальный научный центр Российской академии наук», г. Ялта, Российская \\ Федерация \\ 2 Донской государственный технический университет, г. Ростов-на-Дону, Российская \\ Федерация \\ ${ }^{3}$ Южный федеральный университет, г. Ростов-на-Дону, Российская Федерация \\ *E-mail: valyalta@rambler.ru
}

\begin{abstract}
Аннотация
Ввеление. В работе проведено исследование особенностей фрармакологической регуляции функционального состояния пожилых АюАей с помощью сеансов психоре^аксации и ароматерапии с применением эфирного масла котовника кошачьего различной временной продолжительности. Аля оценки фуункционального состояния анализировали основные параметры серАечно-сосудистой системы, а также субъективную оценку обследуемыми своих самочувствия, активности и настроения.

Новизна работы состоит в том, что впервые было изучено фрармакологическое воздействие эфирного мас^а котовника кошачьего на фрункциональное состояние пожилых ^юАей различной продолжительности (10, 20 и 30 минут) на фроне психорелаксационной записи.
\end{abstract}

Методы. В работе использовались СлеАующие методы и методики: регистрация параметров работы сердечно-сосудистой системы (систолическое, Аиастолическое и пульсовое артериальное Аавление, частота сердечных сокращений, минутный объем крови, ударный объем серАца, серАечный инАекс, коэффрициент эорорективности кровообращения); «Госпитальная шкала тревоги и Аепрессии»; методика исследования быстроты мышления; модифицированная методика корректурной пробы, таблица Иванова-Смоленского; самооценочная метолика Аембо - Рубинштейн в модификации А.М. Прихожан.

В работе приняли участие 324 человека в возрасте от 50 Ао 90 ^ет, в том числе 94 с гипертонией, которые находятся на учете в центрах социального обслуживания гражАан пожилого возраста и инвалиАов г. ЯАты и г. Симфрерополя (Республика Крым). Результаты. В результате проведенного исследования показано, что неинвазивное фрармакологическое воздействие ароматерапии с применением эфирного масла котовника кошачьего оказывает положительное влияние на психодризиологическое, 
психоэмоциональное состояние И умственную работоспособность у АюАей пожи^ого возраста при 10-ти и 20-ти минутных возАействиях.

ОбсужАение результатов. Также в работе было показано, что сеансы аромаре^аксации с эфрирным маслом котовника кошачьего оказывают положительное влияние на функциональное состояние пожилых АюАей, уменьшая тревогу и снижая систолическое и пульсовое кровяное давление.

\section{КАючевые слова}

пожилые ^юли, фрункциональное состояние, фрармакологическая регуляция, эфирное масло, ароматерапия, релаксационная психотерапия, котовник кошачий, субъективное благополучие, тревога, депрессия

\section{Основные положения}

- фрармакологическое воздействие с применением эфирного масла (ЭМ) котовника кошачьего при сочетанном возАействии сеансов психорелаксации и ароматерапии оказывает положительное влияние на психосризиологическое, психоэмоциональное состояние и умственную работоспособность ^юАей пожилого возраста;

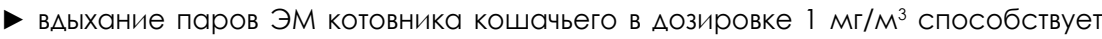
снижению ситуативной тревоги через 10 и 20 минут после аромасеанса, повышению быстроты мышления через 30 минут, увеличению умственной работоспособности, повышению субъективной самооценки общего состояния, самочувствия, настроения, болрости и внимательности через 10, 20 и 30 минут;

- сеансы аромарелаксации ЭМ котовника кошачьего оказывают выраженное Аействие на параметры серАечно-сосудистой системы ^юАей пожилого возраста с гипертонией.

\section{Для цитирования}

Тонковцева В.В., Батура И. А., Воробьева Е. В., Буриков А. А. Особенности фармакологической регуляции функционального состояния пожилых людей // Российский психологический журнал. 2018. Т. 15, № 2. С. 26-59. DOI: 10.21702/rpj.2018.2.2

Материалы статьи получены 05.10.2017 


\title{
Characteristics of the Pharmacological Regulation of Functional States in Elderly Adults
}

\author{
Valentina V. Tonkovtseva ${ }^{1 *}$, Inna A. Batura', Elena V. Vorobyeva ${ }^{2}$, Aleksei A. Burikov ${ }^{3}$ \\ ${ }^{1}$ Nikitsky Botanical Garden, National Research Centre of the Russian Academy of Sciences, \\ Yalta, Russian Federation \\ 2 Don State Technical University, Rostov-on-Don, Russian Federation \\ ${ }^{3}$ Southern Federal University, Rostov-on-Don, Russian Federation \\ *Corresponding author. E-mail: valyalta@rambler.ru
}

\begin{abstract}
Introduction. This paper reports a study of characteristics of pharmacological regulation of functional states in elderly adults by means of psycho-relaxation and aromatherapy sessions of various durations with the use of catnip oil. The assessment of functional states was carried out through the analysis of the main parameters of cardiovascular system and subjective estimates of respondents' health, activity, and mood. This is the first study on the pharmacological effects of catnip essential oil on elderly adults' functional states, depending on the diffusion duration (10,20, and 30 minutes), monitored by psycho-relaxation recording.
\end{abstract}

Methods. The study used the following techniques: (a) recording of cardiovascular parameters (systolic blood pressure, diastolic blood pressure, pulse pressure, heart rate, minute blood volume, heart stroke volume, cardiac index, blood circulation index); (b) the Hospital Anxiety and Depression Scale (HADS); (c) the Technique for Measuring the Speed of Thought; (d) the Proofreading Test (modified version); (e) Ivanov-Smolensky proofreading tables; and (f) self-assessment diagnostic technique by Dembo-Rubinstein (modified by A.M. Prikhozhan).

The study participants were 324 adults aged 50-90 years, including 94 hypertensive respondents who were registered at social services centers for elderly and disabled citizens in Yalta and Simferopol (the Republic of Crimea).

Results. The study results show that a 10- or 20-minute non-invasive pharmacological exposure to aromatherapy with the use of catnip oil can positively affect psychophysiological and psychoemotional states and mental working capacity in elderly adults.

Discussion. The data obtained indicate that aroma-relaxation treatment with the use of catnip essential oil positively affects functional states in elderly adults, reduces anxiety symptoms, and decreases pulse and systolic blood pressure. 


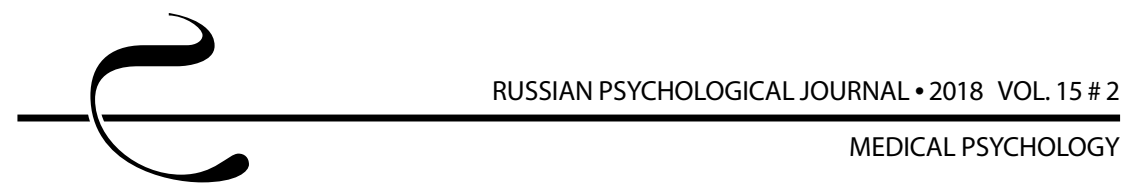

\section{Keywords}

elderly adults, functional state, pharmacological regulation, essential oil, aromatherapy, relaxation psychotherapy, catnip oil, subjective well-being, anxiety, depression

\section{Highlights}

- Pharmacological exposure to catnip essential oil (EO) combined with the psychorelaxation and aromatherapy treatment can positively affect psychophysiological and psychoemotional states and mental working capacity in elderly adults.

- Inhaling catnip essential oil $\left(1 \mathrm{mg} / \mathrm{m}^{3}\right)$ for 10 and 20 minutes reduces situational anxiety. A 30-minute aromatherapy session with the use of catnip essential oil increases the speed of thought. Inhaling catnip essential oil for 10, 20, and 30 minutes increases mental working capacity and subjective self-rating of the overall respondents' condition, health, mood, vitality, and attention.

- Aroma-relaxation treatment with catnip essential oil has a pronounced impact on basic parameters of cardiovascular system in hypertensive elderly adults.

\section{For citation}

Tonkovtseva V.V., Batura I.A., Vorobyeva E.V., Burikov A.A. Characteristics of the Pharmacological Regulation of Functional States in Elderly Adults. Rossiiskii psikhologicheskii zhurnal - Russian Psychological Journal, 2018, V. 15, no. 2, pp. 26-59 (in Russian). DOI: 10.21702/rpj.2018.2.2

Original manuscript received 05.10.2017

\section{Введение}

В связи с увеличением средней продолжительности жизни, как в мире, так и в нашей стране, ростом продолжительности периода трудоспособности и трудовой занятости населения все более актуальной становится проблема сохранения здоровья людей пожилого возраста. Возможности применения природных средств, таких, как эфирные масла растительного происхождения, заслуживают в этой связи самого пристального внимания и изучения как препаратов для неинвазивной фармакологической регуляции функциональных состояний пожилых людей. В Никитском ботаническом саду (Крым) проводятся ставшие традиционными исследования эффективности воздействия различных эфирных масел на функциональное состояние человека, настроение, параметры электроэнцефалограммы и др. [1, 2]. Привлечение пожилых людей проводится через систему центров социального обслуживания, что позволяет делать разрабатываемые подходы к фитореабилитации доступными для широких слоев населения.

Следует отметить, что проблема коррекции функционального состояния, а также изучения психофизиологических механизмов такой коррекции, 
нуждается в дальнейшей разработке [3]. В ряде работ исследовалось фармакологическое влияние эфирных масел на функциональное состояние человека, в том числе было показано, например, повышение эффективности зрительного опознания $[4,5]$. В пожилом возрасте отмечается реорганизация связи внимания и памяти с интеллектуальными показателями [6].

Особое значение для людей пожилого возраста приобретают одоранты, которые способны снижать тревогу и депрессию, такие, например, как эфирное масло котовника кошачьего [7].

Эфирное масло (ЭМ) котовника кошачьего (Nepeta cataria L.) применяется в парфюмерной промышленности как ароматический компонент с приятным запахом, а в народной медицине - в качестве средства для лечения истощения, мигрени, неврастении и пневмонии [8]. Установлено, что ЭМ котовника обладает фитонцидным и антибактериальными действиями, оказывает антибиотический эффект по отношению к стрептококку, стафилококку, клебсиелле, сарцине - 0,0015 г/л, а к синегнойной палочке - 0,0075 г/л при минимальной концентрации данного ЭМ [9].

Нами было показано, что однократный сеанс ЭМ котовника кошачьего у людей среднего и молодого возрастов снижает личностную тревожность, улучшает общее состояние, самочувствие, настроение и работоспособность, а курсовое воздействие также повышает умственную работоспособность и подвижность нейромышечных процессов [10, 11]. Использование ЭМ котовника кошачьего у пожилых людей в низкой концентрации $\left(0,1 \mathrm{mr} / \mathrm{m}^{3}\right)$ оказывает небольшое стимулирующее влияние на умственную работоспособность, небольшое гипотензивное и брадикардическое действие [12]. На наш взгляд, эффективность фармакологического воздействия эфирных масел на функциональное состояние людей пожилого возраста может быть выше при сочетании такого воздействия с релаксационной психотерапией.

Целью данной работы является изучение особенностей фармакологической регуляции функционального состояния пожилых людей с применением

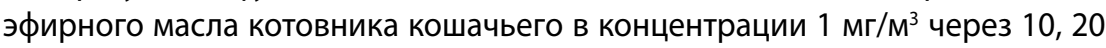
и 30 минут воздействия.

\section{Методы}

Исследование проведено на базе центров социального обслуживания граждан пожилого возраста и инвалидов г. Ялты и г. Симферополя (Республика Крым). В нем приняли участие 324 человека в возрасте от 50 до 90 лет.

Во время исследования испытуемые находились в отдельных затемненных кабинетах в состоянии покоя (положение сидя) группами по 10-12 человек.

Участникам контрольной группы (162 человека) включали психорелаксационную запись продолжительностью 10, 20 или 30 минут. Такая музыкальная 
программа состоит из тихой спокойной музыки со звуками природы и шумом моря в сопровождении мягко звучащего голоса. Экспериментальной группе (162 человека) на протяжении 10, 20 или 30 минут в помещении распыляли эфирное масло котовника кошачьего в концентрации 1 мг/м ${ }^{3}$ и параллельно включали психорелаксационную запись.

Всем испытуемым экспериментальной группы до исследования выполняли накожную и обонятельную пробы, при этом признаков непереносимости данного ЭМ не наблюдалось, восприятие аромата было нейтральным или положительным.

Химический состав эфирного масла (ЭМ) котовника кошачьего (Nepeta cataria L.): $\beta$-непеталактона - 37,09\%, цитронеллола - 18,83\%, а-непеталактона - 11,22\%, гераниола - 7,90\%, $\beta$-кариофиллена $-6,65 \%$, гераниаля $-4,03 \%$, непетовой кислоты - 2,79\%, цис-оцимена - 1,97\%, $\beta$-пинена - 1,29\%, цитронеллаля - 1,03\%, ментола - 1,04\%, менее $1 \%$ - кариофилленоксида, гумулена, сабинена, а-пинена, линалоола, хризантемаля и др.

Для определения психологического состояния пожилых людей до и после аромасеанса проводили такие методики, как:

- «Госпитальная шкала тревоги и депрессии» (методика A. Zigmond, R. Snaith, 1983 г.), предназначенная для выявления и оценки тяжести депрессии и тревоги у взрослых лиц любого возраста [13];

- методика исследования быстроты мышления, позволяющая определить темп выполнения ориентировочных и операциональных компонентов мышления, где показателем быстроты мышления и одновременно показателем подвижности нервных процессов выступает количество правильно выполненных заданий, заключающихся во вставке в слова пропущенных букв [14];

- модификация методики корректурной пробы, таблица ИвановаСмоленского, применяется для оценки внимания, утомляемости, темпа психомоторной деятельности, работоспособности и устойчивости к монотонной деятельности, требующей постоянного сосредоточения внимания [15];

- исследование самооценки по методике Дембо - Рубинштейн в модификации А.М. Прихожан - основано на оценивании испытуемыми ряда показателей. В исследовании с пожилыми людьми выдавали бланк с семью линиями, высота каждой 200 мм, с указанием верхней и нижней точек шкалы. Предлагалось оценить свое состояние и возможности отметкой на шкале по следующим параметрам: общее состояние, самочувствие, настроение, разбитость - работоспособность, напряженность - расслабленность, вялость - бодрость, рассеянность внимательность [16]. 
Для оценки изменения параметров сердечно-сосудистой системы до и после сеанса релаксационной психотерапии измеряли систолическое $\left(\right.$ АД $\left._{\text {сист }}\right)$ и диастолическое (АД диаст $)$ артериальное давление, частоту сердечных сокращений (ЧСC) с помощью аппарата UA-777 фирмы «AD Company Ltd» (Япония). Согласно международной классификации артериального давления JNC-6 была выделена группа из 94 испытуемых с гипертонией (АД сист > 140 мм рт. ст, АД диаст > 90 мм рт. ст.), у которых определяли: пульсовое давление (ПД), минутный объем крови (МОК), ударный объем сердца (УОС), сердечный индекс (СИ), коэффициент эффективности кровообращения (КЭК) $[17,18]$.

Полученные в исследовании данные подвергали статистической обработке. Для решения вопроса о степени соответствия распределений нормальной кривой использовали тест Шапиро - Уилка. Для сопоставления результатов связанных и несвязанных выборок применяли t-критерий Стьюдента, критерий Вилкоксона и Манна - Уитни с помощью программы Statistica AnalystSoft [19].

\section{Результаты}

При оценке психоэмоционального состояния испытуемых с применением «Госпитальной шкалы тревоги и депрессии» исходно контрольная и опытная группа не имели статистически достоверных различий. После оказания фармакологического воздействия на пожилых людей с применением ЭМ котовника кошачьего у пожилых людей через 10 и 20 минут воздействия достоверно снизились проявления тревоги (по сравнению с контрольной группой). Показатели депрессии остались неизменными как в экспериментальной, так и в контрольной группе (таблица 1).

При исследовании влияния ЭМ котовника кошачьего на быстроту мышления людей пожилого возраста (с использованием методики исследования быстроты мышления) статистически достоверной разницы между контрольной и экспериментальной группами в сеансах 10 и 20 минут не выявлено, а через 30 минут в экспериментальной группе было зафиксировано статистически достоверное увеличение правильно выполненных заданий, по сравнению с исходными данными (таблица 2).

Сеансы психорелаксации (контрольная группа) не оказали достоверных изменений на показатели теста для исследования самооценки по методике Дембо - Рубинштейн в модификации А. М. Прихожан. После сеанса психорелаксации с использованием ЭМ котовника кошачьего у людей пожилого возраста через 10, 20 и 30 минут было отмечено улучшение субъективной оценки общего состояния и самочувствия (таблицы 3, 4), повышение настроения (таблица 5) и снижение напряженности (таблица 7). 
Таблица 1. Влияние релаксации с ЭМ котовника кошачьего на психоэмоциональное состояние испытуемых через 10, 20 и 30 минут экспозиции (1 мг/м³; Госпитальная шкала тревоги и Аепрессии, усл. еА.)

Table 1. Effect of a 10-, 20-, and 30-minute relaxation session with catnip EO on respondents' psychoemotional states $\left(1 \mathrm{mg} / \mathrm{m}^{3}\right.$, Hospital Anxiety and Depression Scale, standard units)

\begin{tabular}{|c|c|c|c|c|c|c|c|}
\hline $\begin{array}{l}\text { Шка^а } \\
\text { Scale }\end{array}$ & $\begin{array}{c}\text { Экпери- } \\
\text { мент } \\
\text { исходно } \\
\text { Experi- } \\
\text { ment } \\
\text { (before) }\end{array}$ & $\begin{array}{c}\text { Контромь } \\
\text { Ао } \\
\text { Control } \\
\text { (before) }\end{array}$ & $\begin{array}{c}\text { Экпери- } \\
\text { мент } \\
\text { после } \\
\text { Experi- } \\
\text { ment } \\
\text { (after) }\end{array}$ & $\begin{array}{l}P_{3} \\
P_{E}\end{array}$ & $\begin{array}{c}\text { Контроль } \\
\text { после } \\
\text { Control } \\
\text { (after) }\end{array}$ & $\begin{array}{l}P_{K} \\
P_{C}\end{array}$ & $\begin{array}{l}P_{K / 3} \\
P_{C / E}\end{array}$ \\
\hline \multicolumn{8}{|c|}{$\begin{array}{c}10 \text { мин., } \mathrm{n} \text { (эксп/контр) = } 55 \\
10 \mathrm{~min}, \mathrm{n} \text { (experiment/control) = } 55\end{array}$} \\
\hline $\begin{array}{l}\text { Tревога } \\
\text { Anxiety }\end{array}$ & $7,06 \pm 0,54$ & $7,36 \pm 0,34$ & $5,94 \pm 0,46$ & 0,003 & $6,86 \pm 0,38$ & - & - \\
\hline $\begin{array}{l}\text { Аепрессия } \\
\text { Depression }\end{array}$ & $5,24 \pm 0,45$ & $5,70 \pm 0,40$ & $5,08 \pm 0,44$ & - & $5,24 \pm 0,38$ & - & - \\
\hline \multicolumn{8}{|c|}{$\begin{array}{c}20 \text { мин., } \mathrm{n} \text { (эксп/контр) }=42 \\
20 \mathrm{~min}, \mathrm{n} \text { (experiment/control) }=42\end{array}$} \\
\hline $\begin{array}{l}\text { Тревога } \\
\text { Anxiety }\end{array}$ & $7,88 \pm 0,60$ & $7,52 \pm 0,51$ & $6,67 \pm 0,61$ & 0,002 & $6,86 \pm 0,48$ & - & - \\
\hline $\begin{array}{l}\text { Аeпрессия } \\
\text { Depression }\end{array}$ & $5,86 \pm 0,53$ & $6,52 \pm 0,45$ & $5,71 \pm 0,55$ & - & $5,81 \pm 0,45$ & - & - \\
\hline \multicolumn{8}{|c|}{$\begin{array}{c}30 \text { мин., } \mathrm{n} \text { (эКсп/контр) }=47 \\
30 \mathrm{~min}, \mathrm{n} \text { (experiment/control) }=47\end{array}$} \\
\hline $\begin{array}{l}\text { Тревога } \\
\text { Anxiety }\end{array}$ & $8,11 \pm 0,46$ & $8,11 \pm 0,45$ & $7,45 \pm 0,53$ & - & $7,53 \pm 0,42$ & - & - \\
\hline $\begin{array}{l}\text { Аепрессия } \\
\text { Depression }\end{array}$ & $6,94 \pm 0,47$ & $6,89 \pm 0,37$ & $6,53 \pm 0,46$ & - & $6,74 \pm 0,46$ & - & - \\
\hline
\end{tabular}

Условные обозначения: $P_{э}$ - достоверность различий данных до и после воздействия ЭМ котовника, $P_{\kappa}$ - достоверность различий данных контрольной группы до и после сеанса психорелаксации, $P_{\text {к/з }}{ }^{\prime}$ - достоверность различий данных контрольной и экспериментальной групn $(p<0,05)$.

Legend: $P_{E}$ - significance of differences before and after exposure to catnip $E O, P_{C}$ - significance of differences in the control group before and after the psycho-relaxation session, and $P_{C / E}$-significance of differences between the control and the experimental group $(p<0.05)$. 
Таблица 2. Влияние релаксации с ЭМ котовника кошачьего на быстроту мышления испытуемых через 10, 20 и 30 минут экспозиции (1 мг/м³ , с использованием методики исследования быстроты мышления, шт.)

Table 2. Effect of a 10-, 20-, and 30-minute relaxation session with catnip EO on the respondents' speed of thought ( $1 \mathrm{mg} / \mathrm{m}^{3}$, Technique for Measuring the Speed of Thought, $\mathrm{n}$ )

\begin{tabular}{|c|c|c|c|c|c|}
\hline $\begin{array}{c}\text { Показатель } \\
\text { Index }\end{array}$ & $n$ & $\begin{array}{l}\text { Гpynna } \\
\text { Group }\end{array}$ & $\begin{array}{c}\text { Ao } \\
\text { Before }\end{array}$ & $\begin{array}{c}\text { Пoc^e } \\
\text { After }\end{array}$ & $P$ \\
\hline \multicolumn{6}{|c|}{$\begin{array}{l}10 \mathrm{MиH.} \\
10 \mathrm{~min}\end{array}$} \\
\hline \multirow{2}{*}{$\begin{array}{l}\text { Количество } \\
\text { слов } \\
\text { Words (n) }\end{array}$} & 42 & $\begin{array}{l}\text { Контрольная } \\
\text { Control }\end{array}$ & $28,74 \pm 1,16$ & $27,12 \pm 1,43$ & - \\
\hline & 42 & $\begin{array}{l}\text { Эксперимента^ьная } \\
\text { Experimental }\end{array}$ & $29,93 \pm 1,22$ & $29,86 \pm 1,37$ & - \\
\hline \multirow{2}{*}{$\begin{array}{l}\text { Комичество } \\
\text { ошибок } \\
\text { Errors (n) }\end{array}$} & 42 & $\begin{array}{l}\text { Контрольная } \\
\text { Control }\end{array}$ & $2,12 \pm 0,23$ & $1,74 \pm 0,22$ & - \\
\hline & 42 & $\begin{array}{l}\text { Экспериментальная } \\
\text { Experimental }\end{array}$ & $1,74 \pm 0,30$ & $2,10 \pm 0,29$ & - \\
\hline \multicolumn{6}{|c|}{$\begin{array}{c}20 \mathrm{MuH} . \\
20 \mathrm{~min}\end{array}$} \\
\hline \multirow{2}{*}{$\begin{array}{l}\text { Количество } \\
\text { слов } \\
\text { Words (n) }\end{array}$} & 60 & $\begin{array}{l}\text { Контрольная } \\
\text { Control }\end{array}$ & $29,08 \pm 0,83$ & $28,40 \pm 0,82$ & - \\
\hline & 60 & $\begin{array}{l}\text { Экспериментальная } \\
\text { Experimental }\end{array}$ & $29,00 \pm 1,15$ & $29,55 \pm 0,96$ & - \\
\hline \multirow{2}{*}{$\begin{array}{l}\text { Количество } \\
\text { ошибок } \\
\text { Errors (n) }\end{array}$} & 60 & $\begin{array}{l}\text { Контрольная } \\
\text { Control }\end{array}$ & $1,68 \pm 0,24$ & $1,90 \pm 0,22$ & - \\
\hline & 60 & $\begin{array}{l}\text { Экспериментальная } \\
\text { Experimental }\end{array}$ & $1,32 \pm 0,18$ & $1,42 \pm 0,18$ & - \\
\hline \multicolumn{6}{|c|}{$\begin{array}{c}30 \mathrm{MиH} . \\
30 \mathrm{~min}\end{array}$} \\
\hline \multirow{3}{*}{$\begin{array}{l}\text { Количество } \\
\text { с^ов } \\
\text { Words (n) }\end{array}$} & 47 & $\begin{array}{l}\text { Контро^ьная } \\
\text { Control }\end{array}$ & $23,36 \pm 0,90$ & $24,13 \pm 1,00$ & - \\
\hline & 47 & $\begin{array}{l}\text { Эксперимента^ьная } \\
\text { Experimental }\end{array}$ & $27,74 \pm 1,06$ & $29,45 \pm 0,98$ & 0,03 \\
\hline & & $\begin{array}{l}P_{K / 3} \\
P_{C / E}\end{array}$ & 0,01 & 0,001 & \\
\hline \multirow{2}{*}{$\begin{array}{l}\text { Количество } \\
\text { ошибок } \\
\text { Errors (n) }\end{array}$} & 47 & $\begin{array}{l}\text { Контрольная } \\
\text { Control }\end{array}$ & $1,98 \pm 0,20$ & $1,91 \pm 0,18$ & - \\
\hline & 47 & $\begin{array}{l}\text { Экспериментальная } \\
\text { Experimental }\end{array}$ & $1,62 \pm 0,22$ & $1,43 \pm 0,21$ & - \\
\hline
\end{tabular}

Условные обозначения: $P$ - достоверность различий данных до и после воздействия, $P_{k / 3}$ - достоверность различий данных контрольной и экспериментальной групn ( $p<0,05)$.

Legend: $P$ - significance of differences before and after exposure, $P_{C E}-$ significance of differences between the control and the experimental group $(p<0.05)$. 
Таблица 3. Влияние релаксации с ЭМ котовника кошачьего на общее состояние испытуемых (по показателям теста Аля исследования самооценки по методике Аембо - Рубинштейн в модификкации А.М. Прихожан, 1 мг/м³, мм)

Table 3. Effect of relaxation with catnip EO on the overall respondents' condition (self-assessment diagnostic technique by Dembo-Rubinstein, $1 \mathrm{mg} / \mathrm{m}^{3}, \mathrm{~mm}$ )

\begin{tabular}{|c|c|c|c|c|c|}
\hline $\begin{array}{l}\text { Показатель } \\
\text { Index }\end{array}$ & $n$ & $\begin{array}{l}\text { Группа } \\
\text { Group }\end{array}$ & $\begin{array}{c}\text { Ao } \\
\text { Before }\end{array}$ & $\begin{array}{c}\text { Mocıe } \\
\text { After }\end{array}$ & $P$ \\
\hline \multicolumn{6}{|c|}{$\begin{array}{l}10 \mathrm{MUH} . \\
10 \mathrm{~min}\end{array}$} \\
\hline \multirow{2}{*}{$\begin{array}{l}\text { Общее } \\
\text { состояние } \\
\text { Overall } \\
\text { condition }\end{array}$} & 55 & $\begin{array}{l}\text { Контрольная } \\
\text { Control }\end{array}$ & $140,51 \pm 4,05$ & $145,60 \pm 3,62$ & - \\
\hline & 55 & $\begin{array}{l}\text { Экспери- } \\
\text { мента^ьная } \\
\text { Experimental }\end{array}$ & $136,49 \pm 5,15$ & $154,58 \pm 4,22$ & 2,28543E-08 \\
\hline \multicolumn{6}{|c|}{$\begin{array}{l}20 \mathrm{MиH.} \\
20 \mathrm{~min}\end{array}$} \\
\hline \multirow{3}{*}{$\begin{array}{l}\text { Общее } \\
\text { состояние } \\
\text { Overall } \\
\text { condition }\end{array}$} & 60 & $\begin{array}{l}\text { Контрольная } \\
\text { Control }\end{array}$ & $133,22 \pm 3,65$ & $131,23 \pm 3,55$ & - \\
\hline & 60 & $\begin{array}{l}\text { Экспери- } \\
\text { ментальная } \\
\text { Experimental }\end{array}$ & $132,77 \pm 4,10$ & $148,23 \pm 3,82$ & $2,24116 \mathrm{E}-05$ \\
\hline & & $\begin{array}{l}P_{k / 3} \\
P_{C / E}\end{array}$ & - & 0,01 & \\
\hline \multicolumn{6}{|c|}{$\begin{array}{l}30 \mathrm{MиH.} \\
30 \mathrm{~min}\end{array}$} \\
\hline \multirow{2}{*}{$\begin{array}{l}\text { Общее } \\
\text { состояние } \\
\text { Overall } \\
\text { condition }\end{array}$} & 47 & $\begin{array}{l}\text { Контрольная } \\
\text { Control }\end{array}$ & $150,23 \pm 4,16$ & $152,87 \pm 4,64$ & - \\
\hline & 47 & $\begin{array}{l}\text { Экспери- } \\
\text { ментальная } \\
\text { Experimental }\end{array}$ & $147,91 \pm 5,00$ & $159,38 \pm 4,81$ & $7,12944 \mathrm{E}-05$ \\
\hline
\end{tabular}

Условные обозначения: $P$ - достоверность различий данных до и после воздействия, $P_{k / 3}$ - достоверность различий данных контрольной и экспериментальной групn $(p<0,05)$.

Legend: $P$ - significance of differences before and after exposure, $P_{C / E}$ - significance of differences between the control and the experimental group $(p<0.05)$. 
Таблица 4. Влияние релаксации с ЭМ котовника кошачьего на самочувствие испытуемых (по показателям теста Аля исследования самооценки по методике Аембо - Рубинштейн в модификации А.М. Прихожан, 1 мг/м³, мм)

Table 4. Effect of relaxation with catnip EO on the respondents' health (self-assessment diagnostic technique by Dembo-Rubinstein, $1 \mathrm{mg} / \mathrm{m}^{3}, \mathrm{~mm}$ )

\begin{tabular}{|c|c|c|c|c|c|}
\hline $\begin{array}{l}\text { Показатель } \\
\text { Index }\end{array}$ & $n$ & $\begin{array}{l}\text { Гpyпna } \\
\text { Group }\end{array}$ & $\begin{array}{c}\text { Ao } \\
\text { Before }\end{array}$ & $\begin{array}{c}\text { Mocıe } \\
\text { After }\end{array}$ & $P$ \\
\hline \multicolumn{6}{|c|}{$\begin{array}{l}10 \mathrm{мин.} \\
10 \mathrm{~min}\end{array}$} \\
\hline \multirow{2}{*}{$\begin{array}{l}\text { Самочувствие } \\
\text { Health }\end{array}$} & 55 & $\begin{array}{l}\text { Контрольная } \\
\text { Control }\end{array}$ & $145,38 \pm 3,96$ & $148,20 \pm 3,88$ & - \\
\hline & 55 & $\begin{array}{l}\text { Экспери- } \\
\text { ментальная } \\
\text { Experimental }\end{array}$ & $138,87 \pm 5,25$ & $154,38 \pm 4,48$ & $4,37409 \mathrm{E}-05$ \\
\hline \multicolumn{6}{|c|}{$\begin{array}{l}20 \text { мин. } \\
20 \mathrm{~min}\end{array}$} \\
\hline \multirow{3}{*}{$\begin{array}{l}\text { Самочувствие } \\
\text { Health }\end{array}$} & 60 & $\begin{array}{l}\text { Контрольная } \\
\text { Control }\end{array}$ & $133,47 \pm 3,75$ & $133,55 \pm 3,53$ & - \\
\hline & 60 & $\begin{array}{l}\text { Экспери- } \\
\text { ментальная } \\
\text { Experimental }\end{array}$ & $133,87 \pm 4,18$ & $149,27 \pm 3,77$ & $1,71229 \mathrm{E}-06$ \\
\hline & & $\begin{array}{l}P_{K / 3} \\
P_{C / E}\end{array}$ & - & 0,01 & \\
\hline \multicolumn{6}{|c|}{$\begin{array}{l}30 \text { мин. } \\
30 \mathrm{~min}\end{array}$} \\
\hline \multirow{2}{*}{$\begin{array}{l}\text { Самочувствие } \\
\text { Health }\end{array}$} & 47 & $\begin{array}{l}\text { Контрольная } \\
\text { Control }\end{array}$ & $150,34 \pm 4,47$ & $154,70 \pm 4,54$ & - \\
\hline & 47 & $\begin{array}{l}\text { Экспери- } \\
\text { ментальная } \\
\text { Experimental }\end{array}$ & $\begin{array}{l}142,36 \pm \\
5,95\end{array}$ & $\begin{array}{l}156,19 \pm \\
5,14\end{array}$ & 0,001 \\
\hline
\end{tabular}

Условные обозначения: $P$ - достоверность различий данных до и после воздействия, $P_{k / 3}-$ достоверность различий данных контрольной и экспериментальной групn ( $p<0,05)$.

Legend: $P$ - significance of differences before and after exposure, $P_{C / E}$ - significance of differences between the control and the experimental group $(p<0.05)$. 
Таблица 5. Влияние релаксации с ЭМ котовника кошачьего на настроение испытуемых (по показателям теста Аля исследования самооценки по методике Аембо - Рубинштейн в модификации А.М. Прихожан, 1 мг/м³, мм)

Table 5. Effect of relaxation with catnip EO on the respondents' mood (self-assessment diagnostic technique by Dembo-Rubinstein, $1 \mathrm{mg} / \mathrm{m}^{3}, \mathrm{~mm}$ )

\begin{tabular}{|c|c|c|c|c|c|}
\hline $\begin{array}{c}\text { Показатель } \\
\text { Index }\end{array}$ & $n$ & $\begin{array}{l}\text { Гpynna } \\
\text { Group }\end{array}$ & $\begin{array}{c}\text { Ao } \\
\text { Before }\end{array}$ & $\begin{array}{c}\text { После } \\
\text { After }\end{array}$ & $P$ \\
\hline \multicolumn{6}{|c|}{$\begin{array}{l}10 \mathrm{MUH} . \\
10 \mathrm{~min}\end{array}$} \\
\hline \multirow{2}{*}{$\begin{array}{l}\text { Настроение } \\
\text { Mood }\end{array}$} & 55 & $\begin{array}{l}\text { Контрольная } \\
\text { Control }\end{array}$ & $149,87 \pm 4,18$ & $153,80 \pm 4,12$ & - \\
\hline & 55 & $\begin{array}{l}\text { Экспери- } \\
\text { ментальная } \\
\text { Experimental }\end{array}$ & $143,93 \pm 5,47$ & $156,69 \pm 4,19$ & $1,83065 \mathrm{E}-05$ \\
\hline \multicolumn{6}{|c|}{$\begin{array}{l}20 \mathrm{MHH} . \\
20 \mathrm{~min}\end{array}$} \\
\hline \multirow{3}{*}{$\begin{array}{l}\text { Настроение } \\
\text { моod }\end{array}$} & 60 & $\begin{array}{l}\text { Контрольная } \\
\text { Control }\end{array}$ & $131,15 \pm 4,26$ & $133,10 \pm 3,59$ & - \\
\hline & 60 & $\begin{array}{l}\text { Экспери- } \\
\text { ментальная } \\
\text { Experimental }\end{array}$ & $136,82 \pm 4,23$ & $151,13 \pm 3,71$ & 3,88901E-05 \\
\hline & & $\begin{array}{l}P_{K / 3} \\
P_{C / E}\end{array}$ & - & 0,001 & \\
\hline \multicolumn{6}{|c|}{$\begin{array}{l}30 \mathrm{MUH} . \\
30 \mathrm{~min}\end{array}$} \\
\hline \multirow{2}{*}{$\begin{array}{l}\text { Настроение } \\
\text { Mood }\end{array}$} & 47 & $\begin{array}{l}\text { Контрольная } \\
\text { Control }\end{array}$ & $152,91 \pm 4,03$ & $153,94 \pm 4,64$ & - \\
\hline & 47 & $\begin{array}{l}\text { Экспери- } \\
\text { ментальная } \\
\text { Experimental }\end{array}$ & $147,72 \pm 5,23$ & $159,66 \pm 4,30$ & 0,0003 \\
\hline
\end{tabular}

Условные обозначения: $P$ - достоверность различий данных до и после воздействия, $P_{k / 9}$ - достоверность различий данных контрольной и экспериментальной групп ( $p<0,05)$.

Legend: $P$ - significance of differences before and after exposure, $P_{C E}$ - significance of differences between the control and the experimental group $(p<0.05)$.

Через 10 и 20 минут после проведения аромасеанса у пожилых людей повысилась субъективная самооценка работоспособности (по показателям теста для исследования самооценки по методике Дембо - Рубинштейн в модификации А.М. Прихожан), тогда как через 30 минут статистически значимых изменений этого показателя не выявлено (таблица 6). 
Таблица 6. Влияние релаксации с ЭМ котовника кошачьего на работоспособность испытуемых (по показателям теста Аля исслеАования самооценки по методике Аембо - Рубинштейн в модификации А.М. Прихожан, 1 мг/м³, мМ)

Table 6. Effect of relaxation with catnip EO on the respondents' working capacity (self-assessment diagnostic technique by Dembo-Rubinstein, $1 \mathrm{mg} / \mathrm{m}^{3}, \mathrm{~mm}$ )

\begin{tabular}{|c|c|c|c|c|c|}
\hline $\begin{array}{l}\text { Показатель } \\
\text { Index }\end{array}$ & $n$ & $\begin{array}{l}\text { Гpynna } \\
\text { Group }\end{array}$ & $\begin{array}{c}\text { Ao } \\
\text { Before }\end{array}$ & $\begin{array}{c}\text { Moc^e } \\
\text { After }\end{array}$ & $P$ \\
\hline \multicolumn{6}{|c|}{$\begin{array}{l}10 \mathrm{мин.} \\
10 \mathrm{~min}\end{array}$} \\
\hline \multirow{2}{*}{$\begin{array}{l}\text { Разбитость - } \\
\text { работоспо- } \\
\text { собность } \\
\text { Weakness - } \\
\text { working } \\
\text { capacity }\end{array}$} & 55 & $\begin{array}{l}\text { Контрольная } \\
\text { Control }\end{array}$ & $140,55 \pm 4,82$ & $145,78 \pm 4,92$ & - \\
\hline & 55 & $\begin{array}{l}\text { Экспери- } \\
\text { мента^ьная } \\
\text { Experimental }\end{array}$ & $139,05 \pm 6,06$ & $154,00 \pm 4,65$ & $9,97497 \mathrm{E}-07$ \\
\hline \multicolumn{6}{|c|}{$\begin{array}{l}20 \mathrm{Mин.} \\
20 \mathrm{~min}\end{array}$} \\
\hline \multirow{3}{*}{$\begin{array}{l}\text { Разбитость - } \\
\text { работоспо- } \\
\text { собность } \\
\text { Weakness - } \\
\text { working } \\
\text { capacity }\end{array}$} & 60 & $\begin{array}{l}\text { Контрольная } \\
\text { Control }\end{array}$ & $133,43 \pm 3,68$ & $132,55 \pm 3,60$ & - \\
\hline & 60 & $\begin{array}{l}\text { Экспери- } \\
\text { ментальная } \\
\text { Experimental }\end{array}$ & $132,85 \pm 4,87$ & $146,98 \pm 4,28$ & $5,73516 \mathrm{E}-06$ \\
\hline & & $\begin{array}{l}P_{K / 3} \\
P_{C / E}\end{array}$ & - & 0,01 & \\
\hline \multicolumn{6}{|c|}{$\begin{array}{l}30 \mathrm{Mин.} \\
30 \mathrm{~min}\end{array}$} \\
\hline \multirow{2}{*}{$\begin{array}{l}\text { Разбитость - } \\
\text { работоспо- } \\
\text { собность } \\
\text { Weakness - } \\
\text { working } \\
\text { capacity }\end{array}$} & 47 & $\begin{array}{l}\text { Контрольная } \\
\text { Control }\end{array}$ & $142,57 \pm 5,64$ & $146,02 \pm 5,39$ & - \\
\hline & 47 & $\begin{array}{l}\text { Экспери- } \\
\text { ментальная } \\
\text { Experimental }\end{array}$ & $142,68 \pm 5,68$ & $151,00 \pm 5,53$ & - \\
\hline
\end{tabular}

Условные обозначения: $P$ - достоверность различий данных до и после воздействия, $P_{\text {кө }}$ - достоверность различий данных контрольной и экспериментальной групn $(p<0,05)$.

Legend: $P$ - significance of differences before and after exposure, $P_{C E}-$ significance of differences between the control and the experimental group $(p<0.05)$. 
Таблица 7. Влияние релаксации с ЭМ котовника кошачьего на расслабленность испытуемых (по показателям теста Аля исслеАования самооценки по методике Аембо - Рубинштейн в модификации А.М. Прихожан, 1 мг/м³, мм)

Table 7. Effect of relaxation with catnip EO on the respondents' limpness (self-assessment diagnostic technique by Dembo-Rubinstein, $1 \mathrm{mg} / \mathrm{m}^{3}, \mathrm{~mm}$ )

\begin{tabular}{|c|c|c|c|c|c|}
\hline $\begin{array}{l}\text { Показатель } \\
\text { Index }\end{array}$ & $n$ & $\begin{array}{l}\text { Группа } \\
\text { Group }\end{array}$ & $\begin{array}{c}\text { Ao } \\
\text { Before }\end{array}$ & $\begin{array}{c}\text { Пocıe } \\
\text { After }\end{array}$ & $P$ \\
\hline \multicolumn{6}{|c|}{$\begin{array}{l}10 \mathrm{Mин.} \\
10 \mathrm{~min}\end{array}$} \\
\hline \multirow{2}{*}{$\begin{array}{l}\text { Напряженность - } \\
\text { расслаблен- } \\
\text { ность } \\
\text { Tension - limpness }\end{array}$} & 55 & $\begin{array}{l}\text { Контрольная } \\
\text { Control }\end{array}$ & $133,24 \pm 4,74$ & $139,84 \pm 4,93$ & - \\
\hline & 55 & $\begin{array}{l}\text { Экспери- } \\
\text { мента^ьная } \\
\text { Experimental }\end{array}$ & $133,49 \pm 6,33$ & $151,42 \pm 4,74$ & 0,0003 \\
\hline \multicolumn{6}{|c|}{$\begin{array}{l}20 \text { мин. } \\
20 \mathrm{~min}\end{array}$} \\
\hline \multirow{3}{*}{$\begin{array}{l}\text { Напряженность - } \\
\text { расслаблен- } \\
\text { ность } \\
\text { Tension - limpness }\end{array}$} & 60 & $\begin{array}{l}\text { Контрольная } \\
\text { Control }\end{array}$ & $130,78 \pm 3,63$ & $131,43 \pm 3,45$ & - \\
\hline & 60 & $\begin{array}{l}\text { Экспери- } \\
\text { мента^ьная } \\
\text { Experimental }\end{array}$ & $130,78 \pm 4,07$ & $143,07 \pm 4,81$ & 0,0007 \\
\hline & & $\begin{array}{l}P_{K / 3} \\
P_{C / E}\end{array}$ & - & 0,05 & \\
\hline \multicolumn{6}{|c|}{$\begin{array}{l}30 \mathrm{Mин.} \\
30 \mathrm{~min}\end{array}$} \\
\hline \multirow{2}{*}{$\begin{array}{l}\text { Напряженность - } \\
\text { расслаблен- } \\
\text { ность } \\
\text { Tension - limpness }\end{array}$} & 47 & $\begin{array}{l}\text { Контрольная } \\
\text { Control }\end{array}$ & $145,38 \pm 4,72$ & $149,62 \pm 4,91$ & - \\
\hline & 47 & $\begin{array}{l}\text { Экспери- } \\
\text { ментальная } \\
\text { Experimental }\end{array}$ & $133,51 \pm 6,44$ & $151,45 \pm 5,68$ & 0,0009 \\
\hline
\end{tabular}

Условные обозначения: $P$ - достоверность различий данных до и после воздействия, $P_{k / 9}$ - достоверность различий данных контрольной и экспериментальной групп $(p<0,05)$.

Legend: $P$ - significance of differences before and after exposure, $P_{C E}$ - significance of differences between the control and the experimental group $(p<0.05)$.

Достоверно повысилась субъективная оценка выраженности бодрости и внимательности (по показателям теста для исследования самооценки по методике Дембо - Рубинштейн в модификации А. М. Прихожан) во всех трех экспозициях времени (таблицы 8, 9). 
Таблица 8. Влияние релаксации с ЭМ котовника кошачьего на болрость испытуемых (по показателям теста Аля исследования самооценки по методике Аембо - Рубинштейн в модификации А.М. Прихожан, 1 мг/М³ м мм)

Table 8. Effect of relaxation with catnip EO on the respondents' vitality (self-assessment diagnostic technique by Dembo-Rubinstein, $1 \mathrm{mg} / \mathrm{m}^{3}, \mathrm{~mm}$ )

\begin{tabular}{|c|c|c|c|c|c|}
\hline $\begin{array}{c}\text { Показатель } \\
\text { Index }\end{array}$ & $n$ & $\begin{array}{l}\text { Гpynna } \\
\text { Group }\end{array}$ & $\begin{array}{c}\text { Ao } \\
\text { Before }\end{array}$ & $\begin{array}{c}\text { Moc^e } \\
\text { After }\end{array}$ & $P$ \\
\hline \multicolumn{6}{|c|}{$\begin{array}{l}10 \text { мин. } \\
10 \mathrm{~min}\end{array}$} \\
\hline \multirow{2}{*}{$\begin{array}{l}\text { Вя^ость - } \\
\text { бодрость } \\
\text { Languor - } \\
\text { vitality }\end{array}$} & 55 & $\begin{array}{l}\text { Контрольная } \\
\text { Control }\end{array}$ & $138,15 \pm 4,67$ & $145,60 \pm 5,19$ & - \\
\hline & 55 & $\begin{array}{l}\text { Экспери- } \\
\text { ментальная } \\
\text { Experimental }\end{array}$ & $140,00 \pm 6,10$ & $151,49 \pm 5,47$ & 0,02 \\
\hline \multicolumn{6}{|c|}{$\begin{array}{c}20 \text { мин. } \\
20 \mathrm{~min}\end{array}$} \\
\hline \multirow{3}{*}{$\begin{array}{l}\text { Вя^ость - } \\
\text { болрость } \\
\text { Languor - } \\
\text { vitality }\end{array}$} & 60 & $\begin{array}{l}\text { Контрольная } \\
\text { Control }\end{array}$ & $133,17 \pm 3,68$ & $131,15 \pm 3,45$ & - \\
\hline & 60 & $\begin{array}{l}\text { Экспери- } \\
\text { ментальная } \\
\text { Experimental }\end{array}$ & $133,33 \pm 4,52$ & $148,67 \pm 3,92$ & $1,23459 E-05$ \\
\hline & & $\begin{array}{l}P_{K / 3} \\
P_{C / E}\end{array}$ & - & 0,001 & \\
\hline \multicolumn{6}{|c|}{$\begin{array}{l}30 \text { мин. } \\
30 \mathrm{~min}\end{array}$} \\
\hline \multirow{2}{*}{$\begin{array}{l}\text { Вя^ость - } \\
\text { боАрость } \\
\text { Languor - } \\
\text { vitality }\end{array}$} & 47 & $\begin{array}{l}\text { Контрольная } \\
\text { Control }\end{array}$ & $144,34 \pm 5,31$ & $149,68 \pm 4,79$ & - \\
\hline & 47 & $\begin{array}{l}\text { Экспери- } \\
\text { ментальная } \\
\text { Experimental }\end{array}$ & $142,72 \pm 5,36$ & $153,87 \pm 5,48$ & 0,02 \\
\hline
\end{tabular}

Условные обозначения: $P$ - достоверность различий данных до и после воздействия, $P_{k / 3}$ - достоверность различий данных контрольной и экспериментальной групn ( $p<0,05)$.

Legend: $P$ - significance of differences before and after exposure, $P_{C / E}$ - significance of differences between the control and the experimental group $(p<0.05)$. 
Таблица 9. Влияние релаксации с ЭМ котовника кошачьего на внимательность испытуемых (по показателям теста Аля исследования самооценки по методике

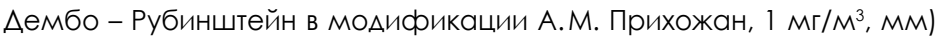

Table 9. Effect of relaxation with catnip EO on the respondents' mindfulness (selfassessment diagnostic technique by Dembo-Rubinstein, $1 \mathrm{mg} / \mathrm{m}^{3}, \mathrm{~mm}$ )

\begin{tabular}{|c|c|c|c|c|c|}
\hline $\begin{array}{c}\text { Показатель } \\
\text { Index }\end{array}$ & $n$ & $\begin{array}{l}\text { Группа } \\
\text { Group }\end{array}$ & $\begin{array}{c}\text { Ao } \\
\text { Before }\end{array}$ & $\begin{array}{c}\text { После } \\
\text { After }\end{array}$ & $P$ \\
\hline \multicolumn{6}{|c|}{$\begin{array}{l}10 \mathrm{MHH} . \\
10 \mathrm{~min}\end{array}$} \\
\hline \multirow{2}{*}{$\begin{array}{l}\text { Рассеянность- } \\
\text { вниматель- } \\
\text { ность } \\
\text { Absent- } \\
\text { mindedness - } \\
\text { mindfulness } \\
\end{array}$} & 55 & $\begin{array}{l}\text { Контрольная } \\
\text { Control }\end{array}$ & $137,42 \pm 5,52$ & $146,16 \pm 5,37$ & - \\
\hline & 55 & $\begin{array}{l}\text { Экспери- } \\
\text { ментальная } \\
\text { Experimental }\end{array}$ & $143,22 \pm 5,47$ & $154,00 \pm 5,09$ & 0,003 \\
\hline \multicolumn{6}{|c|}{$\begin{array}{c}20 \mathrm{MuH} . \\
20 \mathrm{~min}\end{array}$} \\
\hline \multirow{3}{*}{$\begin{array}{l}\text { Рассеянность- } \\
\text { вниматель- } \\
\text { ность } \\
\text { Absent- } \\
\text { mindedness - } \\
\text { mindfulness } \\
\end{array}$} & 60 & $\begin{array}{l}\text { Контрольная } \\
\text { Control }\end{array}$ & $134,02 \pm 3,59$ & $132,32 \pm 3,38$ & - \\
\hline & 60 & $\begin{array}{l}\text { Экспери- } \\
\text { мента^ьная } \\
\text { Experimental }\end{array}$ & $132,38 \pm 4,80$ & $147,37 \pm 3,88$ & 0,0002 \\
\hline & & $\begin{array}{l}P_{K / 3} \\
P_{C / E}\end{array}$ & - & 0,01 & \\
\hline \multicolumn{6}{|c|}{$\begin{array}{l}30 \mathrm{MuH} . \\
30 \mathrm{~min}\end{array}$} \\
\hline \multirow{2}{*}{$\begin{array}{l}\text { Рассеянность - } \\
\text { вниматель- } \\
\text { ность } \\
\text { Absent- } \\
\text { mindedness - } \\
\text { mindfulness }\end{array}$} & 47 & $\begin{array}{l}\text { Контрольная } \\
\text { Control }\end{array}$ & $143,98 \pm 5,44$ & $148,49 \pm 5,12$ & - \\
\hline & 47 & $\begin{array}{l}\text { Экспери- } \\
\text { ментальная } \\
\text { Experimental }\end{array}$ & $144,60 \pm 5,46$ & $154,89 \pm 4,73$ & 0,005 \\
\hline
\end{tabular}

Условные обозначения: $P$ - достоверность различий данных до и после воздействия, $P_{k / 3}$ - достоверность различий данных контрольной и экспериментальной групn $(p<0,05)$.

Legend: $P$ - significance of differences before and after exposure, $P_{C I E}$ - significance of differences between the control and the experimental group $(p<0.05)$.

При оценке влияния 10-ти минутного сеанса психорелаксации в сочетании с аромасеансом ЭМ котовника кошачьего на умственную работоспособность, оцениваемую с применением модифицированной методики корректурной 
пробы, сравнение результатов контрольной и экспериментальной групп показало, что в экспериментальной группе в результате 10-ти минутного сеанса ароматерапии достоверно увеличился темп выполнения задания на 2-й минуте без увеличения количества ошибок. После 20-минутного сеанса ароматерапии с применением ЭМ котовника кошачьего достоверно увеличился темп работы на 1-й минуте при увеличении количества ошибок, и повысилось количество ошибок на 2-й минуте без изменения темпа работы. Через 30 минут вдыхания ЭМ котовника кошачьего достоверно увеличился темп работы на 1-й минуте. У испытуемых контрольной группы на 2-й минуте достоверно снизились темп выполнения работы и количество ошибок после 20-ти минутного сеанса психорелаксации (таблица 10).

Таблица 10. Влияние релаксации с ЭМ котовника кошачьего на умственную работоспособность (1 мг/M³, по показателям корректурной пробы)

Table 10. Effect of relaxation with catnip EO on the respondents' mental working capacity (1 mg/m³ , Proofreading Test)

\begin{tabular}{|c|c|c|c|c|}
\hline $\begin{array}{l}\text { Показатель } \\
\text { Index }\end{array}$ & $\begin{array}{l}\text { Tруппа } \\
\text { Group }\end{array}$ & $\begin{array}{c}\text { ИсхоАНО } \\
\text { Before }\end{array}$ & $\begin{array}{c}\text { Пoc^e } \\
\text { After }\end{array}$ & $P$ \\
\hline \multicolumn{5}{|c|}{10 мин., n (ЭКСП/КОНтр) = 55} \\
\hline \multirow{2}{*}{$\begin{array}{l}\text { Темп } \\
\text { (на } 1 \text { минуте) } \\
\text { Speed } \\
\text { (in the 1st } \\
\text { minute) }\end{array}$} & $\begin{array}{l}\text { Контрольная } \\
\text { Control }\end{array}$ & $235,31 \pm 9,10$ & $238,44 \pm 9,74$ & - \\
\hline & $\begin{array}{l}\text { Экспериментальная } \\
\text { Experimental }\end{array}$ & $244,84 \pm 9,43$ & $249,55 \pm 8,42$ & - \\
\hline \multirow{2}{*}{$\begin{array}{l}\text { Ошибки } \\
\text { (на } 1 \text { минуте) } \\
\text { Errors } \\
\text { (in the 1st } \\
\text { minute) }\end{array}$} & $\begin{array}{l}\text { Контрольная } \\
\text { Control }\end{array}$ & $1,71 \pm 0,27$ & $1,31 \pm 0,21$ & - \\
\hline & $\begin{array}{l}\text { Экспериментальная } \\
\text { Experimental }\end{array}$ & $1,93 \pm 0,27$ & $1,35 \pm 0,34$ & - \\
\hline \multirow{2}{*}{$\begin{array}{l}\text { Темп } \\
\text { (на } 2 \text { минуте) } \\
\text { Speed } \\
\text { (in the 2nd } \\
\text { minute) } \\
\end{array}$} & $\begin{array}{l}\text { Контрольная } \\
\text { Control }\end{array}$ & $206,16 \pm 8,69$ & $218,93 \pm 9,51$ & - \\
\hline & $\begin{array}{l}\text { Эксперимента^ьная } \\
\text { Experimental }\end{array}$ & $219,42 \pm 8,71$ & $243,47 \pm 9,43$ & 0,001 \\
\hline \multirow{2}{*}{$\begin{array}{l}\text { Ошибки } \\
\text { (на } 2 \text { минуте) } \\
\text { Errors } \\
\text { (in the 2nd } \\
\text { minute) }\end{array}$} & $\begin{array}{l}\text { Контрольная } \\
\text { Control }\end{array}$ & $1,25 \pm 0,18$ & $1,15 \pm 0,19$ & - \\
\hline & $\begin{array}{l}\text { Эксперимента^ьная } \\
\text { Experimental }\end{array}$ & $1,22 \pm 0,25$ & $1,35 \pm 0,28$ & - \\
\hline
\end{tabular}




\begin{tabular}{|c|c|c|c|c|}
\hline $\begin{array}{l}\text { Показатель } \\
\text { Index }\end{array}$ & $\begin{array}{l}\text { Tpynna } \\
\text { Group }\end{array}$ & $\begin{array}{l}\text { ИсXOAHO } \\
\text { Before }\end{array}$ & $\begin{array}{l}\text { Tocıe } \\
\text { After }\end{array}$ & $P$ \\
\hline \multicolumn{5}{|c|}{$\begin{array}{c}20 \mathrm{Mин.,} \mathrm{n} \mathrm{(эКсп/Контр)} \mathrm{=} 60 \\
20 \mathrm{~min}, \mathrm{n} \text { (experiment/control) }=60\end{array}$} \\
\hline \multirow{3}{*}{$\begin{array}{l}\text { Темп } \\
\text { (на } 1 \text { минуте) } \\
\text { Speed } \\
\text { (in the 1st } \\
\text { minute) }\end{array}$} & $\begin{array}{l}\text { Контрольная } \\
\text { Control }\end{array}$ & $249,60 \pm 10,29$ & $238,27 \pm 8,84$ & - \\
\hline & $\begin{array}{l}\text { Экспериментальная } \\
\text { Experimental }\end{array}$ & $278,30 \pm 15,73$ & $292,37 \pm 15,23$ & 0,05 \\
\hline & $\begin{array}{l}P_{K / 3} \\
P_{C / E}\end{array}$ & - & 0,01 & \\
\hline \multirow{2}{*}{$\begin{array}{l}\text { Ошибки } \\
\text { (на } 1 \text { минуте) } \\
\text { Errors } \\
\text { (in the 1st } \\
\text { minute) }\end{array}$} & $\begin{array}{l}\text { Контрольная } \\
\text { Control }\end{array}$ & $2,63 \pm 0,38$ & $2,58 \pm 0,36$ & - \\
\hline & $\begin{array}{l}\text { Экспериментальная } \\
\text { Experimental }\end{array}$ & $1,92 \pm 0,25$ & $3,00 \pm 0,39$ & 0,004 \\
\hline \multirow{3}{*}{$\begin{array}{l}\text { Темп } \\
\text { (на } 2 \text { минуте) } \\
\text { Speed } \\
\text { (in the 2nd } \\
\text { minute) }\end{array}$} & $\begin{array}{l}\text { Контрольная } \\
\text { Control }\end{array}$ & $242,10 \pm 8,97$ & $227,48 \pm 8,35$ & 0,02 \\
\hline & $\begin{array}{l}\text { Экспериментальная } \\
\text { Experimental }\end{array}$ & $268,13 \pm 11,03$ & $268,38 \pm 11,50$ & - \\
\hline & $\begin{array}{l}P_{K / 3} \\
P_{C / E}\end{array}$ & - & 0,01 & \\
\hline \multirow{3}{*}{$\begin{array}{l}\text { Ошибки } \\
\text { (на } 2 \text { минуте) } \\
\text { Errors } \\
\text { (in the 2nd } \\
\text { minute) }\end{array}$} & $\begin{array}{l}\text { Контрольная } \\
\text { Control }\end{array}$ & $3,67 \pm 0,43$ & $2,00 \pm 0,32$ & 0,0002 \\
\hline & $\begin{array}{l}\text { Экспериментальная } \\
\text { Experimental }\end{array}$ & $1,82 \pm 0,40$ & $3,05 \pm 0,45$ & 0,02 \\
\hline & $\begin{array}{l}P_{K / 3} \\
P_{C / E}\end{array}$ & 0,01 & - & \\
\hline
\end{tabular}




\begin{tabular}{|c|c|c|c|c|}
\hline $\begin{array}{l}\text { Показате^ь } \\
\text { Index }\end{array}$ & $\begin{array}{l}\text { Tpynna } \\
\text { Group }\end{array}$ & $\begin{array}{l}\text { ИсXOAHO } \\
\text { Before }\end{array}$ & $\begin{array}{l}\text { Toc^e } \\
\text { After }\end{array}$ & $P$ \\
\hline \multicolumn{5}{|c|}{$\begin{array}{c}30 \text { мин., n (эксп/контр) = } 47 \\
30 \mathrm{~min}, \mathrm{n} \text { (experiment/control) = } 47\end{array}$} \\
\hline \multirow{3}{*}{$\begin{array}{l}\text { Темп } \\
\text { (на } 1 \text { минуте) } \\
\text { Speed } \\
\text { (in the 1st } \\
\text { minute) }\end{array}$} & $\begin{array}{l}\text { Контрольная } \\
\text { Control }\end{array}$ & $252,11 \pm 7,80$ & $261,36 \pm 9,40$ & - \\
\hline & $\begin{array}{l}\text { Экспериментальная } \\
\text { Experimental }\end{array}$ & $253,17 \pm 12,74$ & $301,64 \pm 10,75$ & 0,004 \\
\hline & $\begin{array}{l}P_{k / 3} \\
P_{C / E}\end{array}$ & - & 0,01 & \\
\hline \multirow{3}{*}{$\begin{array}{l}\text { Ошибки } \\
\text { (на } 1 \text { минуте) } \\
\text { Errors } \\
\text { (in the 1st } \\
\text { minute) }\end{array}$} & $\begin{array}{l}\text { Контрольная } \\
\text { Control }\end{array}$ & $1,21 \pm 0,20$ & $1,53 \pm 0,23$ & - \\
\hline & $\begin{array}{l}\text { Экспериментальная } \\
\text { Experimental }\end{array}$ & $2,57 \pm 0,54$ & $2,11 \pm 0,48$ & - \\
\hline & $\begin{array}{l}P_{K / 3} \\
P_{C / E}\end{array}$ & 0,05 & & \\
\hline \multirow{3}{*}{$\begin{array}{l}\text { Темп } \\
\text { (на } 2 \text { минуте) } \\
\text { Speed } \\
\text { (in the 2nd } \\
\text { minute) }\end{array}$} & $\begin{array}{l}\text { Контрольная } \\
\text { Control }\end{array}$ & $250,49 \pm 8,02$ & $247,60 \pm 8,20$ & - \\
\hline & $\begin{array}{l}\text { Экспериментальная } \\
\text { Experimental }\end{array}$ & $265,98 \pm 13,56$ & $279,85 \pm 13,29$ & \\
\hline & $\begin{array}{l}P_{k / 3} \\
P_{C / E}\end{array}$ & - & 0,05 & \\
\hline \multirow{2}{*}{$\begin{array}{l}\text { Ошибки } \\
\text { (на } 2 \text { минуте) } \\
\text { Errors } \\
\text { (in the 2nd } \\
\text { minute) }\end{array}$} & $\begin{array}{l}\text { Контрольная } \\
\text { Control }\end{array}$ & $1,49 \pm 0,24$ & $1,34 \pm 0,23$ & - \\
\hline & $\begin{array}{l}\text { Экспериментальная } \\
\text { Experimental }\end{array}$ & $2,28 \pm 0,70$ & $2,66 \pm 0,64$ & - \\
\hline
\end{tabular}

Условные обозначения: $P$ - достоверность различий данных до и после воздействия, $P_{k / 3}$ - достоверность различий данных контрольной и экспериментальной групn $(p<0,05)$.

Legend: $P$ - significance of differences before and after exposure, $P_{C E}-$ significance of differences between the control and the experimental group $(p<0.05)$. 
Исследование параметров сердечно-сосудистой системы людей пожилого возраста с гипертонией позволило выявить статистически достоверные изменения у испытуемых после проведения сеанса психорелаксации совместно с ароматерапией ЭМ котовника кошачьего. После воздействия на обследуемых ЭМ котовника кошачьего в течение 10 минут было выявлено статистически значимое снижение систолического артериального давления по сравнению с данными контрольной группы и исходными показателями на 7,8\% и 9,6\% соответственно. Отмечено достоверное уменьшение величины пульсового артериального давления на 16,6\% сравнительно с контролем и на 19,6\% с исходными показателями. Коэффициент эффективности кровоснабжения также снизился по сравнению с данными контрольной группы и исходными показателями на 17,3\% и 23,7\% (таблица 11).

Таблица 11. Влияние релаксации с ЭМ котовника кошачьего на параметры серАечно-сосудистой системы люАей пожилого возраста с гипертонией (10 минут)

Table 11. Effect of relaxation with catnip EO on cardiovascular system parameters in hypertensive elderly adults (10 minutes)

\begin{tabular}{|c|c|c|c|c|c|c|c|}
\hline \multirow[t]{2}{*}{$\begin{array}{l}\text { Пока- } \\
\text { затель } \\
\text { Index }\end{array}$} & $\begin{array}{c}\text { Контроль } \\
\text { AO } \\
\text { Control } \\
\text { (before) }\end{array}$ & $\begin{array}{l}\text { Контроль } \\
\text { nосле } \\
\text { Control } \\
\text { (affer) }\end{array}$ & \multirow[t]{2}{*}{$\begin{array}{l}P_{K} \\
P_{C}\end{array}$} & $\begin{array}{c}\text { Экспери- } \\
\text { мент Ао } \\
\text { Experi- } \\
\text { ment } \\
\text { (before) }\end{array}$ & $\begin{array}{c}\text { Экспери- } \\
\text { мент } \\
\text { после } \\
\text { Experi- } \\
\text { ment } \\
\text { (after) }\end{array}$ & \multirow[t]{2}{*}{$\begin{array}{l}P_{3} \\
P_{E}\end{array}$} & \multirow[t]{2}{*}{$\begin{array}{l}P_{K / 3} \\
P_{C / E}\end{array}$} \\
\hline & \multicolumn{2}{|c|}{$n=20$} & & \multicolumn{2}{|c|}{$n=20$} & & \\
\hline $\begin{array}{l}\text { AA } \triangle_{\text {сист' }} \\
\text { MM PT. CT. } \\
\text { SBP, } \\
\text { mmHg }\end{array}$ & $\begin{array}{c}157,10 \pm \\
3,11\end{array}$ & $\begin{array}{c}154,50 \pm \\
4,11\end{array}$ & - & $\begin{array}{c}157,50 \pm \\
2,22\end{array}$ & $\begin{array}{c}142,40 \pm \\
3,03\end{array}$ & 0,001 & 0,05 \\
\hline $\begin{array}{l}\mathrm{A \triangle}_{\text {Anacr' }^{\prime}} \\
\text { MM рт. Ст. } \\
\text { DBP, } \\
\mathrm{mmHg}\end{array}$ & $\begin{array}{c}82,00 \pm \\
1,85\end{array}$ & $\begin{array}{c}80,80 \pm \\
2,38\end{array}$ & - & $\begin{array}{c}81,05 \pm \\
1,99\end{array}$ & $\begin{array}{c}80,95 \pm \\
2,00\end{array}$ & - & - \\
\hline $\begin{array}{l}\text { ЧСС, } \\
\text { YA/MИН } \\
H R, \\
\text { beats/min }\end{array}$ & $\begin{array}{c}71,85 \pm \\
1,76\end{array}$ & $\begin{array}{c}68,60 \pm \\
1,61\end{array}$ & 0,002 & $\begin{array}{c}71,95 \pm \\
3,04\end{array}$ & $\begin{array}{c}68,10 \pm \\
2,77\end{array}$ & 0,002 & - \\
\hline
\end{tabular}




\begin{tabular}{|c|c|c|c|c|c|c|c|}
\hline \multirow[t]{2}{*}{$\begin{array}{l}\text { Пока- } \\
\text { затель } \\
\text { Index }\end{array}$} & $\begin{array}{c}\text { Контроль } \\
\text { AO } \\
\text { Control } \\
\text { (before) }\end{array}$ & $\begin{array}{c}\text { Контроль } \\
\text { после } \\
\text { Control } \\
\text { (after) }\end{array}$ & \multirow[t]{2}{*}{$\begin{array}{l}P_{K} \\
P_{C}\end{array}$} & $\begin{array}{c}\text { Экспери- } \\
\text { мент Ао } \\
\text { Experi- } \\
\text { ment } \\
\text { (before) }\end{array}$ & $\begin{array}{c}\text { Экспери- } \\
\text { мент } \\
\text { после } \\
\text { Experi- } \\
\text { ment } \\
\text { (after) }\end{array}$ & \multirow[t]{2}{*}{$\begin{array}{l}P_{3} \\
P_{E}\end{array}$} & \multirow[t]{2}{*}{$\begin{array}{l}P_{K / 3} \\
P_{C / E}\end{array}$} \\
\hline & \multicolumn{2}{|c|}{$n=20$} & & \multicolumn{2}{|c|}{$n=20$} & & \\
\hline $\begin{array}{l}\text { ПА, MM } \\
\text { рт. ст. } \\
\text { PP, } \\
\mathrm{mmHg}\end{array}$ & $\begin{array}{c}75,10 \pm \\
3,45\end{array}$ & $\begin{array}{c}73,70 \pm \\
3,80\end{array}$ & - & $\begin{array}{c}76,45 \pm \\
2,93\end{array}$ & $\begin{array}{c}61,45 \pm \\
2,92\end{array}$ & 0,0004 & 0,05 \\
\hline $\begin{array}{l}\text { yOC, } \mathrm{M \wedge} \\
M B V, \mathrm{ml}\end{array}$ & $\begin{array}{c}46,98 \pm \\
2,66\end{array}$ & $\begin{array}{c}47,00 \pm \\
2,59\end{array}$ & - & $\begin{array}{c}49,45 \pm \\
2,18\end{array}$ & $\begin{array}{c}42,01 \pm \\
2,00\end{array}$ & 0,003 & - \\
\hline $\begin{array}{l}\text { MOK, } \\
\text { N/MHH } \\
\text { HSV, } \\
\text { L/min }\end{array}$ & $\begin{array}{c}3343,68 \pm \\
185,69\end{array}$ & $\begin{array}{c}3210,64 \pm \\
182,24\end{array}$ & - & $\begin{array}{c}3557,55 \pm \\
214,76\end{array}$ & $\begin{array}{c}2892,29 \pm \\
198,18\end{array}$ & 0,0002 & - \\
\hline $\begin{array}{l}\mathrm{Ch}, \\
\wedge / \mathrm{MHH} / \mathrm{M}^{2} \\
\mathrm{Cl}, \\
\mathrm{L} / \mathrm{min} / \mathrm{m}^{2}\end{array}$ & $\begin{array}{c}2002,80 \pm \\
120,83\end{array}$ & $\begin{array}{c}1927,68 \pm \\
122,74\end{array}$ & - & $\begin{array}{c}2089,09 \pm \\
117,83\end{array}$ & $\begin{array}{c}1701,88 \pm \\
113,20\end{array}$ & 0,0002 & - \\
\hline $\begin{array}{l}\text { КЭК } \\
\mathrm{BCl}\end{array}$ & $\begin{array}{c}5370,40 \pm \\
254,32\end{array}$ & $\begin{array}{c}5061,95 \pm \\
289,53\end{array}$ & - & $\begin{array}{c}5486,10 \pm \\
299,66\end{array}$ & $\begin{array}{c}4188,20 \pm \\
260,90\end{array}$ & 0,0001 & 0,05 \\
\hline
\end{tabular}

Условные обозначения: АД сист - систолическое давление; $А Д_{\text {диаст }}$ - диастолическое давление; чСС - частота сердечных сокращений; ПД - пульсовое давление; МОК - минутный объем крови; УОС - ударный объем сердиа; СИ - сердечный индекс; КЭК - коэффичиент эффективности кровообращения; $P_{3}$ - достоверность различий данных до и после воздействия ЭМ котовника; $P_{к}$ - достоверность различий данных контрольной группы до и после сеанса психорелаксачии; $P_{\text {к/3 }}$ - достоверность различий данных контрольной и экспериментальной групn $(p<0,05)$.

Legend: SBP - systolic blood pressure; $D B P$ - diastolic blood pressure; $H R$ - heart rate; $P P$ - pulse pressure; $\mathrm{MBV}$ - minute blood volume; $\mathrm{HSV}$ - heart stroke volume; $\mathrm{Cl}$ - cardiac index; $\mathrm{BCl}$ - blood circulation index; $P_{E}$ - significance of differences before and after exposure to catnip $E O, P_{C}$ - significance of differences in the control group before and after the psycho-relaxation session, and $P_{C / E}$-significance of differences between the control and the experimental group $(p<0.05)$. 
После воздействия на обследуемых ЭМ котовника кошачьего в течение 20-ти минут было выявлено статистически достоверное снижение АД сист по сравнению с данными контрольной группы и исходными показателями на 5,8\% и на 6,9\% соответственно. Показатель пульсового давления достоверно уменьшился только относительно данных, полученных у контрольной группы (на 12,6\%) (таблица 12).

Таблица 12. Влияние релаксации с ЭМ котовника кошачьего на параметры сердечно-сосудистой системы ююдей пожилого возраста с гипертонией (20 минут)

Table 12. Effect of relaxation with catnip EO on cardiovascular system parameters in hypertensive elderly adults (20 minutes)

\begin{tabular}{|c|c|c|c|c|c|c|c|}
\hline \multirow[t]{2}{*}{$\begin{array}{l}\text { Пока- } \\
\text { зате^ь } \\
\text { Index }\end{array}$} & $\begin{array}{c}\text { Контроль } \\
\text { Ао } \\
\text { Control } \\
\text { (before) }\end{array}$ & $\begin{array}{l}\text { Контроль } \\
\text { после } \\
\text { Control } \\
\text { (after) }\end{array}$ & \multirow[t]{2}{*}{$\begin{array}{l}P_{k} \\
P_{C}\end{array}$} & $\begin{array}{c}\text { Экспери- } \\
\text { мент Ао } \\
\text { Experi- } \\
\text { ment } \\
\text { (before) }\end{array}$ & $\begin{array}{c}\text { Экспери- } \\
\text { мент } \\
\text { после } \\
\text { Experi- } \\
\text { ment } \\
\text { (after) }\end{array}$ & \multirow[t]{2}{*}{$\begin{array}{l}P_{3} \\
P_{E}\end{array}$} & \multirow[t]{2}{*}{$\begin{array}{l}P_{k / 3} \\
P_{C / E}\end{array}$} \\
\hline & \multicolumn{2}{|c|}{$n=16$} & & \multicolumn{2}{|c|}{$n=15$} & & \\
\hline $\begin{array}{l}\text { AА } \\
\text { сист' } \\
\text { MM рт. ст. } \\
\text { SBP, } \\
\text { mmHg }\end{array}$ & $\begin{array}{c}154,38 \pm \\
2,16\end{array}$ & $\begin{array}{c}153,00 \pm \\
3,61\end{array}$ & - & $\begin{array}{c}154,80 \pm \\
2,95\end{array}$ & $\begin{array}{c}144,13 \pm \\
2,67\end{array}$ & 0,02 & 0,05 \\
\hline 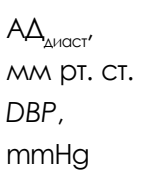 & $\begin{array}{c}85,75 \pm \\
1,34\end{array}$ & $\begin{array}{c}85,19 \pm \\
1,96\end{array}$ & - & $\begin{array}{c}86,40 \pm \\
2,90\end{array}$ & $\begin{array}{c}84,87 \pm \\
2,96\end{array}$ & - & - \\
\hline $\begin{array}{l}\text { ЧCC, } \\
\text { YA/MИH } \\
H R, \\
\text { beats/min }\end{array}$ & $\begin{array}{c}70,63 \pm \\
3,08\end{array}$ & $\begin{array}{c}68,69 \pm \\
2,70\end{array}$ & 0,002 & $\begin{array}{c}70,80 \pm \\
2,61\end{array}$ & $\begin{array}{c}69,67 \pm \\
2,51\end{array}$ & 0,04 & - \\
\hline $\begin{array}{l}\text { ПА, мм } \\
\text { рт. ст. } \\
\text { PP, } \\
\mathrm{mmHg}\end{array}$ & $\begin{array}{c}68,63 \pm \\
2,26\end{array}$ & $\begin{array}{c}67,81 \pm \\
2,83\end{array}$ & - & $\begin{array}{c}68,40 \pm \\
4,05\end{array}$ & $\begin{array}{c}59,27 \pm \\
3,16\end{array}$ & - & 0,05 \\
\hline
\end{tabular}




\begin{tabular}{|c|c|c|c|c|c|c|c|}
\hline \multirow[t]{2}{*}{$\begin{array}{l}\text { Пока- } \\
\text { затель } \\
\text { Index }\end{array}$} & $\begin{array}{c}\text { Контромь } \\
\text { Aо } \\
\text { Control } \\
\text { (before) }\end{array}$ & $\begin{array}{c}\text { Контроль } \\
\text { nосле } \\
\text { Control } \\
\text { (after) }\end{array}$ & \multirow[t]{2}{*}{$\begin{array}{l}P_{k} \\
P_{C}\end{array}$} & $\begin{array}{c}\text { Экспери- } \\
\text { мент Ао } \\
\text { Experi- } \\
\text { ment } \\
\text { (before) }\end{array}$ & $\begin{array}{c}\text { Экспери- } \\
\text { мент } \\
\text { после } \\
\text { Experi- } \\
\text { ment } \\
\text { (after) }\end{array}$ & \multirow[t]{2}{*}{$\begin{array}{l}P_{3} \\
P_{E}\end{array}$} & \multirow[t]{2}{*}{$\begin{array}{l}P_{K / 3} \\
P_{C / E}\end{array}$} \\
\hline & \multicolumn{2}{|c|}{$n=16$} & & \multicolumn{2}{|c|}{$n=15$} & & \\
\hline $\begin{array}{l}\text { YOC, } \mathrm{MA} \\
M B V, \mathrm{ml}\end{array}$ & $\begin{array}{c}41,01 \pm \\
1,46\end{array}$ & $\begin{array}{c}40,94 \pm \\
1,83\end{array}$ & - & $\begin{array}{c}45,83 \pm \\
3,19\end{array}$ & $\begin{array}{c}42,18 \pm \\
2,42\end{array}$ & - & - \\
\hline $\begin{array}{l}\text { MOK, } \\
\text { N/MиH } \\
\text { HSV, } \\
\text { L/min }\end{array}$ & $\begin{array}{c}2922,49 \pm \\
189,94\end{array}$ & $\begin{array}{c}2830,94 \pm \\
194,01\end{array}$ & - & $\begin{array}{c}3240,36 \pm \\
272,24\end{array}$ & $\begin{array}{c}2933,86 \pm \\
190,71\end{array}$ & - & - \\
\hline $\begin{array}{l}\mathrm{Ch}, \\
\mathrm{N} / \mathrm{MnH} / \mathrm{M}^{2} \\
\mathrm{Cl} \\
\mathrm{L} / \mathrm{min} / \mathrm{m}^{2}\end{array}$ & $\begin{array}{c}1702,16 \pm \\
124,89\end{array}$ & $\begin{array}{c}1656,91 \pm \\
136,92\end{array}$ & - & $\begin{array}{c}1858,58 \pm \\
122,37\end{array}$ & $\begin{array}{c}1712,34 \pm \\
101,78\end{array}$ & - & - \\
\hline $\begin{array}{l}\mathrm{K} Э \mathrm{~K} \\
\mathrm{BCl}\end{array}$ & $\begin{array}{c}4890,38 \pm \\
320,37\end{array}$ & $\begin{array}{c}4662,50 \pm \\
298,51\end{array}$ & - & $\begin{array}{c}4805,87 \pm \\
318,47\end{array}$ & $\begin{array}{c}4096,00 \pm \\
216,76\end{array}$ & - & - \\
\hline
\end{tabular}

Условные обозначения: АД сист - систолическое давление; $А Д_{\text {диаст }}$ - диастолическое давление; чСС - частота сердечных сокращений; ПД - пульсовое давление; МОК - минутный объем крови; УОС - ударный объем сердиа; СИ - сердечный индекс; КЭК - коэффичиент эффективности кровообращения; $P_{э}$ - достоверность различий данных до и после воздействия ЭМ котовника; $P_{\kappa}$ - достоверность различий данных контрольной группы до и после сеанса психорелаксации; $P_{\text {к/з }}$ - достоверность различий данных контрольной и экспериментальной групn $(p<0,05)$.

Legend: SBP - systolic blood pressure; DBP - diastolic blood pressure; HR - heart rate; $P P$ - pulse pressure; $M B V$ - minute blood volume; HSV - heart stroke volume; $\mathrm{Cl}$ - cardiac index; $\mathrm{BCl}$ - blood circulation index; $P_{E}$ - significance of differences before and after exposure to catnip $E O, P_{C}$ - significance of differences in the control group before and after the psycho-relaxation session, and $P_{C / E}$-significance of differences between the control and the experimental group $(p<0.05)$.

После воздействия на обследуемых ЭМ котовника кошачьего в течение 30-минутного сеанса психорелаксации в экспериментальной группе достоверно снизилось пульсовое давление как относительно контрольной группы (16,8\%), так и по сравнению с исходными данными (19,3\%), а также уменьшился сердечный индекс (16,9 и 17,1\%) (таблица 13). 
Таблица 13. Влияние релаксации с ЭМ котовника кошачьего на параметры серАечно-сосудистой системы АюАей пожилого возраста с гипертонией (30 минут)

Table 13. Effect of relaxation with catnip EO on cardiovascular system parameters in hypertensive elderly adults (30 minutes)

\begin{tabular}{|c|c|c|c|c|c|c|c|}
\hline \multirow[t]{2}{*}{$\begin{array}{l}\text { Показатель } \\
\text { Index }\end{array}$} & $\begin{array}{c}\text { Контромь } \\
\text { Ao } \\
\text { Control } \\
\text { (before) }\end{array}$ & $\begin{array}{c}\text { Контроль } \\
\text { после } \\
\text { Control } \\
\text { (after) }\end{array}$ & \multirow[t]{2}{*}{$\begin{array}{l}P_{K} \\
P_{C}\end{array}$} & $\begin{array}{c}\text { Экспери- } \\
\text { мент Ао } \\
\text { Experi- } \\
\text { ment } \\
\text { (before) }\end{array}$ & $\begin{array}{c}\text { Экспери- } \\
\text { мент } \\
\text { после } \\
\text { Experi- } \\
\text { ment } \\
\text { (after) }\end{array}$ & \multirow[t]{2}{*}{$\begin{array}{l}P_{3} \\
P_{E}\end{array}$} & \multirow[t]{2}{*}{$\begin{array}{l}P_{\mathrm{k} / \mathrm{s}} \\
P_{\mathrm{C} / \mathrm{E}}\end{array}$} \\
\hline & \multicolumn{2}{|c|}{$n=13$} & & \multicolumn{2}{|c|}{$n=10$} & & \\
\hline 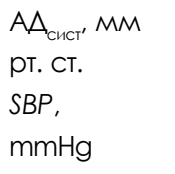 & $\begin{array}{l}154,38 \pm \\
3,32\end{array}$ & $\begin{array}{l}149,92 \pm \\
3,66\end{array}$ & - & $\begin{array}{l}154,90 \pm \\
3,82\end{array}$ & $\begin{array}{l}138,70 \pm \\
5,10\end{array}$ & 0,005 & - \\
\hline $\begin{array}{l}\mathrm{AA}_{\text {Anact' }^{\prime}} \mathrm{MM} \\
\text { PT. CT. } \\
\text { DBP, } \mathrm{mmHg}\end{array}$ & $\begin{array}{l}80,31 \pm \\
2,75\end{array}$ & $\begin{array}{l}77,54 \pm \\
1,95\end{array}$ & - & $\begin{array}{l}80,30 \pm \\
3,64\end{array}$ & $\begin{array}{l}78,50 \pm \\
1,96\end{array}$ & - & - \\
\hline $\begin{array}{l}\text { ЧСС, } \\
\text { УА/MИН } \\
H R, \\
\text { beats/min }\end{array}$ & $\begin{array}{l}72,92 \pm \\
3,51\end{array}$ & $\begin{array}{l}70,08 \pm \\
3,56\end{array}$ & 0,02 & $\begin{array}{l}73,70 \pm \\
2,03\end{array}$ & $\begin{array}{l}69,80 \pm \\
1,62\end{array}$ & 0,01 & - \\
\hline $\begin{array}{l}\text { ПА, мM } \\
\text { Рт. ст. } \\
\text { РP, } \mathrm{mmHg}\end{array}$ & $\begin{array}{l}74,08 \pm \\
3,89\end{array}$ & $\begin{array}{l}72,38 \pm \\
3,20\end{array}$ & - & $\begin{array}{l}74,60 \pm \\
5,55\end{array}$ & $\begin{array}{l}60,20 \pm \\
5,48\end{array}$ & 0,005 & 0,05 \\
\hline $\begin{array}{l}\text { yOC, } \mathrm{MA} \\
M B V, \mathrm{ml}\end{array}$ & $\begin{array}{l}48,85 \pm \\
2,97\end{array}$ & $\begin{array}{l}49,67 \pm \\
1,66\end{array}$ & - & $\begin{array}{l}50,88 \pm \\
4,27\end{array}$ & $\begin{array}{l}44,76 \pm \\
3,35\end{array}$ & - & \\
\hline
\end{tabular}




\begin{tabular}{|c|c|c|c|c|c|c|c|}
\hline \multirow[t]{2}{*}{$\begin{array}{l}\text { Показатель } \\
\text { Index }\end{array}$} & $\begin{array}{c}\text { Контроль } \\
\text { Aо } \\
\text { Control } \\
\text { (before) }\end{array}$ & $\begin{array}{c}\text { Контроль } \\
\text { после } \\
\text { Control } \\
\text { (after) }\end{array}$ & \multirow[t]{2}{*}{$\begin{array}{l}P_{K} \\
P_{C}\end{array}$} & $\begin{array}{c}\text { Экспери- } \\
\text { мент Ао } \\
\text { Experi- } \\
\text { ment } \\
\text { (before) }\end{array}$ & $\begin{array}{c}\text { Экспери- } \\
\text { мент } \\
\text { после } \\
\text { Experi- } \\
\text { ment } \\
\text { (after) }\end{array}$ & \multirow[t]{2}{*}{$\begin{array}{l}P_{3} \\
P_{E}\end{array}$} & \multirow[t]{2}{*}{$\begin{array}{l}P_{K / 3} \\
P_{C / L}\end{array}$} \\
\hline & \multicolumn{2}{|c|}{$n=13$} & & \multicolumn{2}{|c|}{$n=10$} & & \\
\hline $\begin{array}{l}\text { MOK, ^/Мин } \\
\text { HSV, L/min }\end{array}$ & $\begin{array}{l}3593,63 \pm \\
312,98\end{array}$ & $\begin{array}{l}3497,03 \pm \\
235,89\end{array}$ & - & $\begin{array}{l}3742,49 \pm \\
333,14\end{array}$ & $\begin{array}{l}3110,59 \pm \\
226,69\end{array}$ & 0,01 & \\
\hline $\begin{array}{l}\mathrm{Cl}, \\
\wedge / \mathrm{MHH} / \mathrm{M}^{2} \\
\mathrm{Cl}, \mathrm{L} / \mathrm{min} / \mathrm{m}^{2}\end{array}$ & $\begin{array}{l}2054,64 \pm \\
162,19\end{array}$ & $\begin{array}{l}2009,58 \pm \\
117,81\end{array}$ & - & $\begin{array}{l}2013,99 \pm \\
183,61\end{array}$ & $\begin{array}{l}1670,20 \pm \\
125,20\end{array}$ & 0,01 & 0,05 \\
\hline $\begin{array}{l}\mathrm{K} Э \mathrm{~K} \\
\mathrm{BCl}\end{array}$ & $\begin{array}{l}5425,62 \pm \\
408,55\end{array}$ & $\begin{array}{l}5077,92 \pm \\
342,37\end{array}$ & - & $\begin{array}{l}5485,10 \pm \\
418,68\end{array}$ & $\begin{array}{l}4184,90 \pm \\
365,97\end{array}$ & 0,005 & - \\
\hline
\end{tabular}

Условные обозначения: АД сист - систолическое давление; $А Д_{\text {даст }}$ - диастолическое давление; ЧСС - частота сердечных сокращений; ПД - пульсовое давление; МОК - минутный объем крови; УОС - ударный объем сердиа; СИ - сердечный индекс; КЭК - коэффичиент эффективности кровообращения; $P_{э}$ - достоверность различий данных до и после воздействия ЭМ котовника; $P_{\kappa}$ - достоверность различий данных контрольной группы до и после сеанса психорелаксации; $P_{\text {k/з }}^{\kappa}$ - достоверность различий данных контрольной и экспериментальной групn $(p<0,05)$.

Legend: SBP - systolic blood pressure; $D B P$ - diastolic blood pressure; $H R$ - heart rate; $P P$ - pulse pressure; $\mathrm{MBV}$ - minute blood volume; $\mathrm{HSV}$ - heart stroke volume; $\mathrm{Cl}$ - cardiac index; $\mathrm{BCl}$ - blood circulation index; $P_{E}$ - significance of differences before and after exposure to catnip $E O, P_{C}$-significance of differences in the control group before and after the psycho-relaxation session, and $P_{C / E}$-significance of differences between the control and the experimental group $(p<0.05)$.

\section{Обсуждение результатов}

У пожилых людей выраженность тревоги находится в обратной зависимости с субъективным ощущением благополучия [20]. В связи с этим, полученные в нашей работе данные о возможности с применением ароматерапии ЭМ котовника кошачьего снижать выраженность тревоги, имеют хорошие перспективы для практического применения. 
В нашей работе на исследуемой выборке пожилых людей не получены данные о влиянии ароматерапии с применением ЭМ котовника кошачьего на уменьшение выраженности депрессии (по шкале госпитальной тревоги и депрессии). Однако, на материале самооценочной методики Дембо Рубинштейн в модификации А.М. Прихожан, нами получены данные об эффективности ароматерапии с применением ЭМ котовника кошачьего в сочетании с сеансами психорелаксации в отношении субъективно оцениваемых параметров настроения, самочувствия, общего состояния и др. В связи с этим отметим, что антидепрессантные свойства эфирного масла котовника кошачьего были отмечены в результате проведения исследований на животных [21]; они также отмечаются в специальной литературе, посвященной имеющим антидепрессивное фармакологическое воздействие на человека медицинским растениям, произрастающим на территории стран бывшего СССР [22]. В литературе по фармацевтической биологии также указывается, что успокоительное действие препаратов растений рода Nepeta на центральную нервную систему, как представляется, опосредовано работой ГАМКергической нейромедиаторной системы [23].

Сопоставление эффективности различных методов терапии депрессивных проявлений у пожилых людей показало, что наиболее эффективны сочетанные подходы в терапии депрессий у пожилых людей, использующие множество методов [24].

Использование в нашей работе методики исследования быстроты мышления, позволяющей оценить темп выполнения ориентировочных и операциональных компонентов мышления, позволило установить, что сочетание 30-минутного сеанса ароматерапии ЭМ котовника кошачьего с психорелаксацией способствует ускорению быстроты мышления пожилых людей. Известно, что в пожилом возрасте ухудшение когнитивных функций начинается со снижения скорости обработки информации, - это показано, например, в исследовании здоровых пожилых людей в возрасте 61-90 лет [25]. Сохранная скорость мышления и хорошие когнитивные показатели могут обеспечиваться за счет регулярных социальных интеракций (общение с членами семьи, живущими близко и далеко, общение по телефону, со сверстниками и т. д.). Даже небольшое количество социального взаимодействия в день (10 минут) может способствовать познавательной работе [26].

В свою очередь, верно и обратное положение о том, что сохранные показатели мышления имеют важное значение для поддержания хороших социальных связей у людей пожилого возраста, поскольку способствуют правильному пониманию и интерпретации эмоций и поведения, мотивов других людей. В этой связи, говоря о характеристиках мышления пожилых 
людей, важных для осуществления успешных социальных интеракций, удобно обратиться к понятию модели психического. Модель психического психологический феномен (заключающийся в формировании способности понимать степень информационной осведомленности окружающих людей и на этой основе строить с ними взаимодействие), рассматриваемый как важный показатель развития мышления на ранних этапах онтогенеза [27]. Исследования модели психического у пожилых людей, как способности к пониманию своего состояния и состояния других людей, а также к распознаванию ложных ошибок мышления, показали, что у пожилых людей, как правило, имеется дефицит данных функций [28] при общем гетерогенном характере изменений способности понимания психического мира [29]. Поэтому применение фармакологического воздействия с применением ароматерапии эфирными маслами открывает дополнительные перспективы и в этом плане.

В результате применения в нашей работе методики корректурной пробы можно сказать, что с увеличением продолжительности сеансов фармакологического воздействия ЭМ котовника кошачьего (от 10-ти к 20-ти и 30-ти минутам соответственно) растет быстрота увеличения темпа выполнения задания, что свидетельствует о большей эффективности для когнитивных функций пожилых людей сеансов ароматерапии продолжительностью от 20-ти минут и более.

В нашей работе были получены данные относительно фармакологического воздействия различной продолжительности аромасеансов ЭМ котовника кошачьего на параметры сердечно-сосудистой системы людей пожилого возраста с гипертонией. Было показано статистически значимое снижение систолического артериального давления, а также уменьшение значения пульсового артериального давления. В составе фенольных соединений котовника кошачьего значительная доля принадлежит хлорогеновой кислоте, которая выступает ингибитором окисления липопротеидов низкой плотности (которое может впоследствии вызывать повреждение артерий) и способствует предотвращению сердечно-сосудистых заболеваний [30, 31].

Изучение функционального состояния дает ценную информацию для оказания психологической помощи и сопровождения у людей разного возраста [32]. Фармакологическая регуляция функционального состояния пожилых людей с применением эфирных масел, в частности, масла котовника кошачьего, позволяет существенно улучшить показатели мышления, внимания, субъективной оценки собственного здоровья, активности и настроения, уменьшить проявления тревоги, а также может служить вспомогательным средством, ингибирующим развитие сердечно-сосудистых заболеваний. 


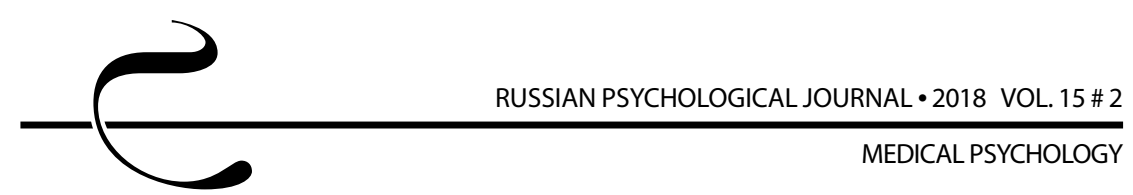

\section{Заключение}

Таким образом, исследование сочетанного воздействия сеансов психорелаксации и ароматерапии подтвердили полученные нами ранее результаты о положительном влиянии ЭМ котовника кошачьего на психофизиологическое, психоэмоциональное состояние и умственную работоспособность человека, в том числе у людей пожилого возраста. Так, вдыхание паров ЭМ котовника кошачьего в дозировке $1 \mathrm{mr} / \mathrm{M}^{3}$ способствовало снижению выраженности тревоги через 10 и 20 минут после аромасеанса, повышению быстроты мышления и подвижности нервных процессов через 30 минут, увеличению умственной работоспособности, улучшению общего состояния, самочувствия, настроения, бодрости и внимательности через 10, 20 и 30 минут.

Исследование параметров сердечно-сосудистой системы людей пожилого возраста с гипертонией выявило, что сеансы аромарелаксации ЭМ котовника кошачьего снижают систолическое и пульсовое артериальное давление, способствуют более экономичной работе сердца и сердечно-сосудистой системы в целом.

\section{Литература}

1. Кириллова А. В., Панова С. А., Лесова Л.Д. Сравнительная оценка влияния эфирных масел на психофизиологический статус человека // Ученые записки Таврического национального университета им. В.И. Вернадского. Серия «Биология, химия». 2011. Т. 24 (63), № 2. С. 150-156.

2. Борода Т. В., Тонковцева В. В., Серобаба Л. А., Середина О. С., Борисова Е. В., Максимова И. Н., Овчаренко Ю. П., Сущенко Л. Г., Державичкая Н. И., Страшко И. Ю., Грицкевич О. И., Кулик Н. И., Самотковская Т. А., Ярош А. М. Влияние эфирного масла можжевельника виргинского в разных концентрациях на психоэмоциональное состояние, умственную работоспособность и память человека // Бюллетень Государственного Никитского ботанического сада. 2015. № 114. С. 44-48.

3. Айдаркин Е. К. Функциональное состояние: физиологические механизмы // Человеческий фактор: проблемы психологии и эргономики. 2013. № 4 (67). С. 58-62.

4. Айдаркин Е. К., Кундупьян О. Л., Кундупьян Ю. Л. Метод аромакоррекции функционального состояния человека в процессе когнитивной деятельности // Человеческий фактор: проблемы психологии и эргономики. 2014. № 1 (68). С. 43-48.

5. Айдаркин Е. К., Кундупьян О. Л., Кундупьян Ю. Л., Архиня А. П., Бибов М. Ю. Психофизиологические показатели сложной когнитивной деятельности в отсутствии и присутствии розмарина // Валеология. 2014. № 1. C. 5-14. 
6. Разумникова О. М., Вольф Н. В. Реорганизация связи интеллекта с характеристиками внимания и памяти при старении // Журнал высшей нервной деятельности им. И. П. Павлова. 2017. Т. 67, № 1. С. 55-67.

7. Kennedy D. O., Little W., Haskell C. F., Scholey A. B. Anxiolytic effects of a combination of Melissa officinalis and Valeriana officinalis during laboratory induced stress // Phytotherapy Research. 2006. Vol. 20, Issue 2. P. 96-102. DOI: $10.1002 /$ ptr.1787

8. Либусь О. К., Работягов В.Д., Кутько С. П., Хлыпенко Л. А. Эфиромасличные и пряно-ароматические растения. Херсон: Айлант, 2004. 272 с.

9. Капелев О.И. Антимикробные и фитонцидные свойства котовника лимонного // Основные направления научных исследований по интенсификации эфиромасличного производства. Ч. 2. Симферополь, 1985. С. 74-75.

10. Тонковцева В. В., Ярош А. М. Влияние на нервную систему человека курсового воздействия эфирным маслом котовника кошачьего // Таврический медико-биологический вестник. 2012. Т. 15, № 1 (57). С. 321-327.

11. Тонковцева В. В., Ярош А. М. Влияние курсового воздействия эфирными маслами лаванды узколистной и котовника кошачьего на психоэмоциональное состояние, умственную работоспособность и нейромоторные процессы человека в условиях курортной рекреации // Сборник научных трудов ГНБС. 2015. Т. 141. С. 65-78.

12. Тонковцева В. В., Бекмамбетов Т. Р., Бакова Н. Н., Ярош А. М. Влияние дыхания эфирным маслом котовника кошачьего в низкой концентрации на психофизиологическое состояние пожилых людей // Бюллетень ГНБС. 2015. Вып. 116. С. 73-76.

13. Zigmond A. S., Snaith R. P. The hospital anxiety and depression scale // Acta Psychiatrica Scandinavica. 1983. Vol. 67, Issue 6. P. 361-370.

14. Черемискина И. И. Методические указания для практических занятий по курсу «Специальный практикум по психологии». Методики диагностики свойств мышления. Владивосток: ИПК МГУ им. адм. Г.И. Невельского, 2007.51 c. URL: http://msun.ru/upload/folders/edu lit/kaf/phsihology/030. pdf (Accessed 25.05.2018).

15. Яньшин П. В. Клиническая психодиагностика личности. Учебно-методическое пособие. 2-е изд., испр. СПб.: Речь, 2007. 320 с.

16. Райгородский Д.Я. Практическая психодиагностика. Методики и тесты. Учебное пособие. Самара: Издательский дом «БАХРАХ-М», 2001. 672 с.

17. The Sixth Report of the Joint National Committee on Prevention, Detection, Evaluation, and Treatment of High Blood Pressure // Archives of Internal Medicine. 1997. Vol. 157, Issue 21. P. 2413-2446. DOI: 10.1001/archinte.1997.00440420033005 
18. Ошевенский Л. В., Крылова Е. В., Уланова Е. А. Изучение состояния здоровья человека по функциональным показателям организма: Учебно-методическое пособие. Нижний Новгород: Изд-во ННГУ им. Н. И. Лобачевского, 2007. 67 с.

19. AnalystSoft Inc. Дружелюбная статистика для ПК // URL: www.analystsoft. com/ru (Accessed 25.05.2018).

20. Pérez-García A. M., Oliván S., Bover R. Subjective Well-being in Heart Failure Patients: Influence of Coping and Depressive Symptoms // International Journal of Behavioral Medicine. 2014. Vol. 21, Issue 2. P. 258-265. DOI: 10.1007/s12529-013-9311-4

21. Bernardi M. M., Kirsten T. B., Salzgeber S. A., Ricci E. L., Romoff P., Guilardi Lago J. H., \& Lourenço L. M. Antidepressant-like effects of an apolar extract and chow enriched with Nepeta cataria (catnip) in mice // Psychology \& Neuroscience. 2010. Vol. 3, Issue 2. P. 251-258. DOI: 10.3922/j.psns.2010.2.015

22. Mamedov N., Mamadalieva N. Medicinal Plants from Countries of Former USSR Used for Treatment of Depression // Herbal Medicine in Depression / C. Grosso (Ed.). Springer, Cham, 2016. P. 183-258. DOI: 10.1007/978-3-319-14021-6 6

23. Galati E. M., Miceli N., Galluzzo M., Taviano M. F. \& Tzakou O. Neuropharmacological Effects of Epinepetalactone from Nepeta sibthorpii Behavioral and Anticonvulsant Activity // Pharmaceutical Biology. 2004. Vol. 42, Issue 6. P. 391-395. DOI: 10.1080/13880200490885059

24. Frazer C. J., Christensen H., Griffiths K. M. Effectiveness of treatments for depression in older people //The Medical Journal of Australia. 2005. Vol. 182, Issue 12. P. 627-632.

25. Pauli L., Daseking M., Petermann F., StemmlerM. Zusammenhänge zwischen den kognitiven Leistungen in einem Demenzscreening (SKT) und in einem Intelligenztest (WAIS-IV). Welche kognitiven Leistungseinbußen im Alter sprechen für einen möglichen pathologischen Abbauprozess? // Zeitschrift für Gerontologie und Geriatrie. 2017.Vol.51, Issue 3.P.266-274.DOI: 10.1007/s00391-017-1263-X

26. Ybarra O., Burnstein E., Winkielman P., et al Mental Exercising Through Simple Socializing: Social Interaction Promotes General Cognitive Functioning // Personality and Social Psychology Bulletin. 2008. Vol. 34, Issue 2. P. 248-259. DOI: $10.1177 / 0146167207310454$

27. Ермаков П. Н., Воробьева Е. В., Кайдановская И. А., Стрельникова Е. О. Модель психического и развитие мышления у детей дошкольного возраста // Экспериментальная психология. 2016. Vol. 9, № 3. C. 72-80. DOI: $10.17759 /$ exppsy.2016090306

28. Nazlidou E.-I., Moraitou D. Theory of mind in aging: A critical presentation of contradictory findings and divergent views (In Greek) // Hellenic Journal of Psychology. 2016. Vol. 13, Issue 3. P. 116-146. 
29. Сергиенко Е. А., Мелехин А. И. Модель психического: гетерогенность изменений в пожилом и старческом возрасте // Человек. Сообщество. Управление. 2016. Т. 17, № 1. С. 26-41.

30. Палий А. Е., Палий И. Н., Марко Н. В., Работягов В. Д. Биологически активные вещества Nepeta Cataria L. // Бюллетень Государственного Никитского ботанического сада. 2016. № 118. С. 37-44.

31. Tisserand R., Young R. Essential Oil Safety: A Guide for Health Care Professionals: 2nd Edition. Churchil Livingstone Elsevier, 2014. 784 p. DOI: 10.1016/C2009-0-52351-3

32. Воробьева Е. В., Шейко С. О., Ермаков П.Н. Мотивационные особенности студентов-психологов как составляющие их функционального состояния // Психология психических состояний: актуальные теоретические и прикладные проблемы: материалы II-ой Всероссийской научной конференции: в 2-х частях. Казань: Отечество, 2013. С. 141-146.

\section{References}

1. Kirillova A. V., Panova S. A., Lesova L. D. Comparative assessment of the effect of essential oils on the psychophysiological status of the human. Uchenye zapiski Tavricheskogo natsional'nogo universiteta im. V. I. Vernadskogo. Seriya "Biologiya, khimiya" - Scientific Notes of V. I. Vernadsky Crimean Federal University. Series Biology and Chemistry, 2011, V. 24 (63), no. 2, pp. 150-156 (in Russian).

2. Boroda T. V., Tonkovtseva V. V., Serobaba L. A., Seredina O. S., Borisova E. V., Maksimova I. N., Ovcharenko Yu. P., Sushchenko L. G., Derzhavitskaya N. I., Strashko I. Yu., Gritskevich O. I., Kulik N. I., Samotkovskaya T. A., Yarosh A. M. Impact of various concentrations of Virginia cedarwood essential oil on the psychoemotional state, mental working capacity, and memory of the person. Byulleten' Gosudarstvennogo Nikitskogo botanicheskogo sada - Bulletin of the State Nikitsky Botanical Gardens, 2015, no. 114, pp. 44-48 (in Russian).

3. Aidarkin E. K. A functional state: Physiological mechanisms. Chelovecheskii faktor: problemy psikhologii i rgonomiki-Human Factors: Problems of Psychology and Ergonomics, 2013, no. 4 (67), pp. 58-62 (in Russian).

4. Aidarkin E. K., Kundup'yan O. L., Kundup'yan Yu. L. The method of aromacorrection of human functional states during cognitive activities. Chelovecheskii faktor: problemy psikhologii i rgonomiki-Human Factors: Problems of Psychology and Ergonomics, 2014, no. 1 (68), pp. 43-48 (in Russian).

5. Aidarkin E. K., Kundup'yan O. L., Kundup'yan Yu. L., Arkhinya A. P., Bibov M. Yu. Psychophysiological indicators of complex cognitive activities in the absence or presence of rosemary. Valeologiya - Journal of Health and Life Sciences, 2014, no. 1, pp. 5-14 (in Russian). 
6. Razumnikova O. M., Vol'f N. V. Aging-induced reorganization of association between intelligence and characteristics of attention and memory. Zhurnal vysshei nervnoi deyatel'nosti im. I. P. Pavlova - I. P. Pavlov Journal of Higher Nervous Activity, 2017, V. 67, no. 1, pp. 55-67 (in Russian).

7. Kennedy D. O., Little W., Haskell C. F., Scholey A. B. Anxiolytic effects of a combination of Melissa officinalis and Valeriana officinalis during laboratory induced stress. Phytotherapy Research, 2006, V. 20, Issue 2, pp. 96-102. DOI: $10.1002 /$ ptr.1787

8. Libus' O. K., Rabotyagov V. D., Kut'ko S. P., Khlypenko L. A. Efiromaslichnye i pryano-aromaticheskie rasteniya [Aromatic and spicy-aromatic plants]. Kherson, Ailant Publ., 2004. 272 p.

9. Kapelev O. I. Anti-microbial and anti-bacterial properties of lemon catnip. In: Osnovnye napravleniya nauchnykh issledovanii po intensifikatsii efiromaslichnogo proizvodstva. Ch. 2. [The main directions of scientific research on the intensification of essential oil production: Part 2]. Simferopol, 1985, pp. 74-75.

10. Tonkovtseva V. V., Yarosh A. M. Impact of a course exposure to catnip essential oil on the human nervous system. Tavricheskiy Mediko-Biologicheskiy Vestnik, 2012, V. 15, no. 1 (57), pp. 321-327 (in Russian).

11. Tonkovtseva V. V., Yarosh A. M. Impact of a course of aromatherapy with the essential oils of lavender and catnip on human psycoemotional state, mental working capacity, and neuromotor processes during resort recreation. Sborniknauchnykh trudov GNBS - Works of the State Nikitsky Botanical Gardens, 2015, V. 141, pp. 65-78 (in Russian).

12. Tonkovtseva V. V., Bekmambetov T. R., Bakova N. N., Yarosh A. M. Impact of the inhalation of a low concentration of catnip essential on elderly adults' psychophysiological state. Byulleten' Gosudarstvennogo Nikitskogo botanicheskogo sada - Bulletin of the State Nikitsky Botanical Gardens, 2015, V. 116, pp. 73-76 (in Russian).

13. Zigmond A. S., Snaith R. P. The hospital anxiety and depression scale. Acta Psychiatrica Scandinavica, 1983, V. 67, Issue 6, pp. 361-370.

14. Cheremiskina I. I. Methodical guidance for practical training in the 'Special practical work on psychology' course: Techniques for diagnosing thinking attributes. Vladivostok, Institute of Advanced Training, Admiral Nevelskoy Maritime State University Publ., 2007. 51 p. Available at: http://msun.ru/ upload/folders/edu lit/kaf/phsihology/030.pdf (Accessed 25 May 2018).

15. Yan'shin P. V. Klinicheskaya psikhodiagnostika lichnosti [Clinical psychodiagnostics of personality]. St. Petersburg, Rech' Publ., 2007. 320 p.

16. Raigorodskii D. Ya. Prakticheskaya psikhodiagnostika. Metodiki i testy [Practical psychodiagnostics: Techniques and tests]. Samara, Bakhrakh-M Publ., $2001.672 \mathrm{p}$. 
17. The sixth report of the Joint National Committee on Prevention, Detection, Evaluation, and Treatment of High Blood Pressure. Archives of Internal Medicine, 1997, V. 157, Issue 21, pp. 2413-2446. DOI: 10.1001/archinte.1997.00440420033005

18. Oshevenskii L. V., Krylova E. V., Ulanova E. A. Izuchenie sostoyaniya zdorov'ya cheloveka po funktsional'nym pokazatelyam organizma [Studying health by functional parameters of human organism]. Nizhny Novgorod Lobachevsky State University of Nizhni Novgorod Publ., 2007. 67 p.

19. AnalystSoft Inc. A friendly statistics package for PC. [Online]. Available at: www.analystsoft.com/ru (Accessed 25 May 2018).

20. Pérez-García A. M., Oliván S., Bover R. Subjective well-being in heart failure patients: Influence of coping and depressive symptoms. International Journal of Behavioral Medicine, 2014, V. 21, Issue 2, pp. 258-265. DOI: 10.1007/s12529-013-9311-4

21. Bernardi M. M., Kirsten T. B., Salzgeber S. A., Ricci E. L., Romoff P., Guilardi Lago J. H., \& Lourenço L. M. Antidepressant-like effects of an apolar extract and chow enriched with Nepeta cataria (catnip) in mice. Psychology \& Neuroscience, 2010, V. 3, Issue 2, pp. 251-258. DOI: 10.3922/j.psns.2010.2.015

22. Mamedov N., Mamadalieva N. Medicinal plants from countries of former USSR used for treatment of depression. In: C. Grosso (ed.) Herbal Medicine in Depression. Springer, Cham, 2016, pp. 183-258. DOI: 10.1007/978-3-319-14021-6 6

23. Galati E. M., Miceli N., Galluzzo M., Taviano M. F. \& Tzakou O. Neuropharmacological effects of epinepetalactone from nepeta sibthorpii behavioral and anticonvulsant activity. Pharmaceutical Biology, 2004, V. 42, Issue 6, pp. 391-395. DOI: 10.1080/13880200490885059

24. Frazer C. J., Christensen H., Griffiths K. M. Effectiveness of treatments for depression in older people. The Medical Journal of Australia, 2005, V. 182, Issue 12, pp. 627-632.

25. Pauli L., Daseking M., Petermann F., Stemmler M. Zusammenhänge zwischen den kognitiven Leistungen in einem Demenzscreening (SKT) und in einem Intelligenztest (WAIS-IV). Welche kognitiven Leistungseinbußen im Alter sprechen für einen möglichen pathologischen Abbauprozess? Zeitschrift für Gerontologie und Geriatrie, 2017, V. 51, Issue 3, pp. 266-274. DOI: 10.1007/s00391-017-1263-x

26. Ybarra O., Burnstein E., Winkielman P., et al. Mental exercising through simple socializing: Social interaction promotes general cognitive functioning. Personality and Social Psychology Bulletin, 2008, V. 34, Issue 2, pp. 248-259. DOI: $10.1177 / 0146167207310454$

27. Ermakov P. N., Vorob'eva E. V., Kaidanovskaya I. A., Strel'nikova E. O. Model of the mental and the development of thinking in preschool children. 
Eksperimental'naya psikhologiya - Experimental Psychology, 2016, V. 9, no. 3, pp. 72-80 (in Russian). DOI: 10.17759/exppsy.2016090306

28. Nazlidou E.-I., Moraitou D. Theory of mind in aging: A critical presentation of contradictory findings and divergent views. Hellenic Journal of Psychology, 2016, V. 13, Issue 3, pp. 116-146 (in Greek).

29. Sergienko E. A., Melekhin A. I. Model of the mental: Heterogeneity of changes in the old and very old age. Chelovek. Soobshchestvo. Upravlenie - Human. Community. Management, 2016, V. 17, no. 1, pp. 26-41 (in Russian).

30. Palii A. E., Palii I. N., Marko N. V., Rabotyagov V. D. Biologically active substances: Nepeta Cataria L. Byulleten' Gosudarstvennogo Nikitskogo botanicheskogo sada - Bulletin of the State Nikitsky Botanical Gardens, 2016, no. 118, pp. 37-44 (in Russian).

31. Tisserand R., Young R. Essential oil safety: A guide for health care professionals: 2nd edition. Churchil Livingstone Elsevier, 2014. 784 p. DOI: 10.1016/C2009-0-52351-3

32. Vorob'eva E. V., Sheiko S. O., Ermakov P. N. Motivatsionnye osobennosti studentov-psikhologov kak sostavlyayushchie ikh funktsional'nogo sostoyaniya [Motivational characteristics of psychology students as components of their functional states]. Materialy II-oi Vserossiiskoi nauchnoi konferentsii Psikhologiya psikhicheskikh sostoyanii: aktual'nye teoreticheskie i prikladnye problemy [Proc. the 2nd All-Russian Scientific Conference "Psychology of mental states: Urgent theoretical and applied problems"]. Kazan, Otechestvo Publ., 2013, pp. 141-146. 